\title{
The Effects of University Affirmative Action Policies on the Human Capital Development of Minority Children: Do Expectations Matter?
}

\author{
Ronald Caldwell Jr. ${ }^{1}$ \\ Department of Economics \\ University of Kansas \\ rcald@ku.edu
}

Revised: July 11, 2010

Working Paper

\begin{abstract}
:
Research shows that minority children enter the labor market with lower levels of acquired skill than their white counterparts. The causes of this skill gap, however, are not entirely understood. This paper analyzes one possible cause: the impact of a perceived lack of future opportunities on the human capital investment decisions of minority children and parents. Using NLSY79 data, I take advantage of changes in affirmative action laws regarding university admissions as a natural experiment. I test for changes in a variety of child and parental human capital investment variables such as time spent studying and parental involvement for children below the age of 15 . The results show that time spent studying among $7^{\text {th }}$ and $8^{\text {th }}$ grade blacks in the affected states is significantly lower. The results for parental input variables show a fairly consistent negative trend among black parents of younger children. Additionally, cognitive achievement tests are examined and show significant results among the same age groups.
\end{abstract}

JEL Classifications: J15, J24

Keywords: affirmative action, skill gaps, human capital investment.

\footnotetext{
${ }^{1}$ I would like to thank Donna Ginther, Richard Hartman, Tom Hazlet, Richard Johnston, Ted Juhl, Lawrence Katz, Shelly Lundberg, Derek Neal, Eugene Silberberg, Alexandre Skiba, Sean Sullivan, Byron Tsang, Bruce Wang, and seminar participants at the University of Washington, Oklahoma State University, Virginia Tech University, the University of Victoria, the 2008 Southern Economic Association conference, the 2009 Society of Labor Economists conference, and the 2009 Western Economic Association conference.
} 


\section{Introduction}

Research has shown that much of the differences in wages that exist between whites and minorities can be attributed to differences in skill level that exist prior to labor market entry (Neal and Johnson 1996). Additionally, it has been found that these skill gaps exist at very early ages, even before children enter primary school (Carneiro, Heckman, and Masterov (2005), Todd and Wolpin (2004), Fryer and Levitt (2004, 2005)). What is not entirely known is why the skill gaps exist and, therefore, what role various policies may have in mitigating this issue. This paper examines one possible cause for the existence of these skill gaps. Namely that minorities perceive a world in which they expect to have fewer opportunities than whites and respond to this by investing less in human capital development when young. This concept has been suggested in the literature (Lundberg and Startz (1983), Lundberg and Startz (2000), Neal (2005), Carneiro, Heckman, and Masterov (2005), Todd and Wolpin (2007)), but, to my knowledge, has received very little attention empirically.

To test the hypothesis that minority parents and children respond to a perceived lack of future opportunities by investing less in human capital development I take advantage of the changes in affirmative action laws regarding university admissions that occurred during the mid 1990s. In a theoretical sense, the removal of affirmative action should have both an income and substitution effect on the human capital investment decisions of children. For underrepresented minorities, the removal of affirmative action makes it more difficult to be accepted into college with the same set of human capital investment. The child may either invest more to make up for this loss (income effect), or 
shift their time into other, non human capital activities, due to the perceived reduction in return to human capital development (substitution effect).

Using several direct measures of child and parental inputs into human capital development, such as hours spent studying, parental involvement in homework activities, and how often parents read to younger children, I find fairly consistent and significantly negative effects on human capital investment among black children and parents relative to whites and blacks from unaffected states. The results for investment variables are very closely mirrored by those for cognitive achievement outcomes. Overall, these results suggest that perceived limits on future opportunities may play a role in human capital investment among minority children and parents, and therefore may be a factor in the existence of the skill gap.

\section{Theoretical Framework}

I propose a two-period labor-leisure choice model of the form:

$$
\begin{aligned}
& \operatorname{Max} \mathrm{U}=\mathrm{U}\left(\mathrm{Y}_{2}, \mathrm{~L}_{1}\right) \\
& \begin{aligned}
\text { s.t. } \mathrm{H}_{1} & =\mathrm{T}_{1}-\mathrm{L}_{1} \\
\text { s.t. } Y_{2} & =\int_{0}^{\mathrm{H}_{1}} E\left[f\left(H_{1}, S\right)\right]+Y^{0} \quad \text { (budget constraint) } \\
& =\mathrm{E}\left[\mathrm{F}\left(\mathrm{H}_{1}, \mathrm{~S}\right)\right]-\mathrm{E}[\mathrm{F}(0)]+\mathrm{Y}^{0}
\end{aligned}
\end{aligned}
$$

where $Y_{2}$ is the discounted sum of earnings for the child in the second period, $Y^{0}$ consists of factors affecting lifetime earnings unrelated to the stock of human capital, $\mathrm{L}_{1}$ is time spent in leisure activities during the first period, $\mathrm{H}_{1}$ is time spent on human capital investment during the first period, $T_{1}$ is the total time available to split between leisure and human capital investment in the first period, S represents the decision to attend 
college by the child conditional on being admitted, and $E\left[f\left(H_{1}, S\right)\right]$ is the expected marginal rate of return to human capital investment.

Second period income is a function of the human capital investment of the child when young and whether or not the child attends college. Here college operates as an intermediary step between periods 1 and 2. In period one, the child makes a decision between consuming leisure and investing in human capital. At the end of period one the child either attends or does not attend college and then earns $\mathrm{Y}_{2}$ in period two based on their decisions in period 1 and their ability to attend college. Whether or not the individual attends college is determined by the admission decisions of the college such that Prob $(S=1)=G\left(H_{1}\right)$. The child will be accepted into college if a threshold $\left(G^{*}\right)$ is met given their level of human capital development and other factors affecting admission decisions. In this case we assume the presence of an affirmative action program in university admissions that, for a minority child, increases the probability that (G*) will be met for any given level of $\mathrm{H}_{1}$.

If affirmative action is eliminated then it becomes less likely that a minority will be accepted into college for any given level of $\mathrm{H}_{1}$. It is fairly straightforward to derive a result where we have both an income and substitution effect in response to changes in the affirmative action laws and an ambiguous theoretical outcome.

\section{Affirmative Action and Higher Education}

The legal basis for the use of race based admissions criteria by universities prior to 1996 was primarily the result of the 1978 U.S. Supreme Court decision Regents of the University of California v. Bakke. ${ }^{2}$ The 1978 decision established the legality of using race as a factor in college admissions, stating that colleges and universities may use

\footnotetext{
${ }^{2} 438$ U.S. 265 (1978).
} 
admissions programs that take into account race in order to help foster diversity, however they could not use separate admissions procedures for minority candidates or quotas. This ruling set the stage for the inclusion of race in the decision making process for many academic admissions programs for the following twenty years.

\subsection{Challenges to Affirmative Action}

On March 18, 1996 the U.S. Court of Appeals for the $5^{\text {th }}$ Circuit, covering Louisiana, Mississippi, and Texas, ruled on Hopwood v. Texas ${ }^{3}$ involving a challenge to the University of Texas Law School admissions policies that included targeted percentages of Hispanic and black students. The court held that the affirmative action programs used were unconstitutional and that educational diversity should not be recognized as a compelling state interest. ${ }^{4}$ In 1997 the Texas Attorney General announced that all universities in Texas should adopt a race-neutral admission criteria which was followed by a state law setting uniform admissions policies for all universities within Texas. This law forbade the explicit use of race in admissions policies but did include the automatic admission into public universities in Texas for all high school seniors graduating in the top ten percent of their graduating class. Similar follow-up steps were not undertaken in either Mississippi or Louisiana and it is unclear what impact, if any, the Hopwood decision had on minorities in those states.

In November of 1996 voters in California passed Proposition 2095 , which banned all California affirmative action programs in public college admissions, government hiring, and government contracting, with 54 percent of the popular vote. According to

\footnotetext{
${ }^{3} 78$ F.3d 932 ( $5^{\text {th }}$ Cir. 1996), abrogated by Grutter v. Bollinger, 539 U.S. 306 (2003), as recognized in Bourdais v. New Orleans, 485 F.3d 294, 300 n.7 (5 ${ }^{\text {th }}$ Cir. 2007)

${ }^{4}$ The Supreme Court refused to hear the case on appeal, so the impact of the ruling was restricted to the $5^{\text {th }}$ circuit. Texas v. Hopwood, 518 U.S. 1033 (1996) (mem.)

${ }^{5}$ CAL. Const. art. I,§ 31.
} 
exit polling data, voting for Proposition 209 largely followed racial lines with approximately $59.2 \%$ of white voters, $37.4 \%$ of Hispanic voters, and only $18.2 \%$ of black voters voting in support. ${ }^{6}$ The proposition ultimately took effect on November $3^{\text {rd }} 1997$ after being delayed in the courts for almost a year. Although the proposition was not passed until late 1996 and did not take effect until the following year, it was well publicized and debated throughout much of 1996.

Figures 1 to 3 show some of the descriptive impact of the banning of affirmative action on the University of California system of schools. Figure 1 shows admit rates as a percent of total applications by race for the University of California system from 1994 to 2004. In 1998, the first entering class following the enactment of the ban shows a strong drop in admit rates for black students. Figure 2 shows application and admit rates for blacks into the UC system as a percent of the total 18 year old black population in California for years 1994 to 1999. Admit rates as a percent of the total 18 year old black population in California dropped slightly in 1997, the year prior to the policy becoming binding, and dropped further in subsequent years. The initial drop, however, may be explained by the drop in application rates in 1997. This is relevant, because in 1997 the law had passed, but was not binding yet and suggests that blacks may have been altering their behavior prior to the law being enacted. Figure 3 shows the change in admit rates among blacks as a percent of total applications for the two most selective schools in the UC system, Berkeley and UCLA.

There have been other state level prohibitions or challenges on the use of affirmative action policies for university admissions over the past decade. Washington

\footnotetext{
${ }^{6}$ Alvarez and Bedolla (2004), taken from Voter News Service exit polling data.
} 
State passed Initiative 200 in November of 1998, Florida passed a law that banned race and gender preferences in college admissions in 2001, and Michigan has had a pair of cases, Gratz v. Bollinger ${ }^{7}$ and Grutter v. Bollinger ${ }^{8}$, brought before the courts regarding the use of race in admissions policies. The latter case was ultimately appealed to the U.S. Supreme Court where, on June 23, 2003, the court upheld the University of Michigan's Law School admission policy and effectively overturned the Hopwood v. Texas decision.

\subsection{Literature on Affirmative Action Bans}

There does exist a growing literature within economics that examines the impact of these policy changes on the behavior of minorities (Long 2004a, 2004b, 2007; Card and Krueger 2005; Brown and Hirschman 2006; Dickson 2006). ${ }^{9}$ These studies have primarily focused on the decisions of high school children as they prepare to enter college and therefore are looking at responses to policies that alter the immediate constraints facing the children. However, they do suggest that the policy changes are relevant enough to alter the behavior of older children and therefore it is certainly plausible that younger children or the parents of younger children might respond to such a change in the landscape of opportunities facing minorities.

\section{Data}

I use the 1979 National Longitudinal Survey of Youth (NLSY79) and the Children of the NLSY79 (CNLSY79). The NLSY79 began as a nationally representative sample of 12,686 men and women who were fourteen to twenty-one years old in 1979,

\footnotetext{
${ }^{7} 539$ U.S. $244(2003)$

${ }^{8} 539$ U.S. 306 (2003)

${ }^{9}$ Long (2004) finds that the minority-white gap in SAT reports sent to colleges widened following the end of affirmative action in California and Texas. Brown and Hirschman (2006) find that application rates among minorities in Washington State declined following the enactment of I-200. Dickson (2006) finds that the percent of blacks and Hispanics applying to college in Texas immediately after the end of affirmative action dropped significantly.
} 
and the CNLSY79 consists of all children born to women from the original NLSY79 cohort. Interviews for the CNLSY79 have been conducted biannually since the survey was initiated in 1986. Access was granted to the restricted use version of the data that allowed me to put a state-identifier with each individual in the survey.

Although the original NLSY79 was a nationally representative sample, the CNLSY79 is not. The CNLSY79 is heavily weighted with first born children and children of young mothers. ${ }^{10}$ In order to account for this, sample weights included in the data are used throughout this study to adjust estimates to be nationally representative. Additionally, since the sample includes children born to the original NLSY79 cohort, children of recent immigrants are not included in the data. As a result, Hispanics in the sample are unlikely to correspond closely to the current Hispanic population in the U.S. Empirical results, therefore, will primarily focus on the behavior of blacks relative to whites. Hispanics are kept in the sample as an additional comparison group. ${ }^{11}$

Only children known to be residing with their mother at the time of the survey were included in the analysis. This was necessary to ensure that the mother's background information was relevant for the child included in the sample. Additionally, I omitted children who were residing outside of the U.S. at the time of the survey.

The CNLSY79 data contain a number of behavioral variables for both the child and mother that may have a direct impact on the level of human capital development. The key dependent variables used in the study are briefly outlined below.

\subsection{Weekly Hours Spent on Homework by the Child}

\footnotetext{
${ }^{10} 45.2 \%$ of the total observation years in the sample are from first-born children, and the mean age at birth for the mothers in the sample is approximately 24 years.

${ }^{11}$ The inclusion of Hispanics is potentially useful as a control for unobservable schooling impacts since blacks and Hispanics tend to belong to similar schools.
} 
I use four direct measures of hours spent doing homework each week from the CNLSY. Beginning in 1996, each child was asked how many hours are spent on homework in school and how many hours are spent on homework after school each week. Additionally, the mother was asked to estimate the number of hours spent by the child each week on math homework and on writing homework respectively. ${ }^{12}$ The redundancy of these questions asked of both the parent and child independently provides a means to test the reliability of the results.

\subsection{Parental Involvement Variables}

There are a number of questions within the data that document the mother's involvement with the child. Given that I am concerned with parental activities related to the human capital development of the child, I constrain my analysis to variables directly related to involvement with study activities and schooling. Among the variables examined are child self reports concerning how often parents help with homework and how often parents check on homework. Each of these questions have been asked since 1996. In each case the child was given six choices as possible responses, ranging from never to everyday.

In addition to the child self report variables I also look at the question asked of the mother on how often the mother reads to the child. This question has been included in the CNLSY survey since its inception in 1986, so a nice baseline is provided with regard to parental behavior prior to the changes in policy. Unlike other responses used in the study, this question is only asked of mothers up to the child age of nine and is asked separately

\footnotetext{
${ }^{12}$ The 1996 and 1998 version of the survey round parental responses to the nearest hour, however the 2000 and 2002 versions allow for a more continuous measure by adding two additional zeros on the end of each response. (i.e. 3 hours is coded as 300). These data were divided by 100 to more closely match responses from earlier waves of the survey. As a result, responses in the latter years include fractional hours while earlier responses do not.
} 
for mothers of children aged zero to two, three to five, and six to nine. I include this question to observe possible changes in parental behavior toward younger children. This variable has been used frequently in the literature and serves as a proxy for overall involvement by the parents in the human capital development of younger children.

\subsection{Cognitive Assessment}

The cognitive assessment measure used in the analysis is the Peabody Individual Achievement Test (PIAT) for Mathematics. This assessment test was administered to all children in the sample between the ages of five and fourteen during each wave of the survey. The advantage of using this test as a measure of cognitive ability is that it has been administered repeatedly to children over the age of five, providing a development profile for each child in the sample.

The PIAT math test consists of 84 multiple-choice questions of increasing difficulty, beginning with elementary arithmetic and progressing to advanced concepts in geometry and trigonometry. Raw scores were used as opposed to percentile or age adjusted standardized scores in order to provide an absolute measure of ability that allows for the measurement of gains over time as children age. ${ }^{13}$ This particular measure of child ability is well suited for the measurement of changes in achievement as children age since the same test is given to children in all age groups. Additionally, the PIAT math assessment has the advantage of having a high completion rate within the CNLSY79 dataset. ${ }^{14}$ The high completion rate within the sample coupled with the fact that all

\footnotetext{
13 The primary results are not sensitive to this choice.

${ }^{14}$ The 2000 survey had a valid completion rate of 93.4\% for black children, 92.5\% for Hispanics, and 90.8\% for whites. Source: NLSY79 Child \& Young Adult Data Users Guide, Table 2.14.
} 
children in the sample are given the test helps to mitigate the issue of selection bias that would exist with using SAT scores or other similar measures.

\subsection{Covariates}

The use of NLSY data allows for a fairly rich set of family and individual background variables. The regressions control for the mother's highest grade completed, birth order of the child, child's gender, age of the child, grade, whether or not the child lived in an urban area, and the presence of a spouse or partner within the household. ${ }^{15}$ Summary statistics for covariates are provided in table 1.

\section{Empirical Analysis and Results}

The estimating strategy is as follows. First, I attempt to establish a link between the period in which the affirmative action policies occurred and changes in educational expectations for younger minority children in those states. Second, I examine possible impacts on human capital investment variables. Finally, I analyze if there are impacts on cognitive achievement for groups that closely match those for whom changes in human capital investments were observed.

In all phases of the analysis four states were excluded due to concerns about the status of affirmative action laws with regards to university admissions in those states. Mississippi and Louisiana were excluded as they are part of the $5^{\text {th }}$ circuit and thus were also covered under the Hopwood decision, however Hopwood was followed by official changes in policy in Texas which did not occur in either Mississippi or Louisiana. As such, it is unclear what, if any, impact the Hopwood decision would have had in these

\footnotetext{
${ }^{15}$ Analyses were also performed using net family income, family size, and mother's employment status to account for differences in these variables and as a control on the possible impact of components of California's Proposition 209 that extended beyond university admissions. Inclusion of these variables required a reduction in sample sizes and primary results remained relatively similar, so reported results are restricted to the more general set of variables.
} 
states. Washington was omitted due to a significant lack of observations regarding minorities within the CNLSY data. The Florida case is more problematic due to the elimination of affirmative occurring much later and following significant debate lasting several years. The length of the debate in Florida prior to the actual banning of affirmative action, and that it had to be taken as a credible threat, given what had already occurred in California and Texas, creates some ambiguity in determining exactly when minorities in Florida may have been legitimately responding to these threats. As a result I have focused on California and Texas, however the inclusion of these four omitted states will be examined as part of the sensitivity analysis.

\subsection{Expectations}

Given the many possible alternative explanations for minorities investing less in human capital development I begin the empirical analysis by examining child responses to survey questions within the data regarding their expected educational attainment during their lifetime. The question provides for a number of possible responses ranging from high school dropout to post-graduate education. These responses were collapsed into two categories: some college and beyond or high school degree or less. Responses were available from 1988 to 2002, so difference-in-difference-in-differences methodology was employed to determine if there was a significant drop in expectations about attending college for blacks in the affected states following the policy changes relative to whites and children of all races and ethnicities from unaffected states. Estimation was performed using a probit model:

$$
\operatorname{Prob}\left(\text { Expects to Attend College }_{i t}=1\right)=I\left(Y_{i t}\right)
$$

where: 
$Y_{i t}=C+\beta_{1}$ Black $_{i}+\beta_{2}$ Hispanic $_{i}+\beta_{3}$ Caltex $_{i t}+\beta_{4}$ Caltex $_{i t} *$ Black $_{i}$

$+\beta_{5}$ Caltex $_{i t} *$ Hispanic $_{i}+\beta_{6}$ Policy $_{t} *$ Black $_{i}+\beta_{7}$ Policy $_{t} *$ Hispanic $_{i}$

$+\beta_{8}$ Policy $_{t}^{*}$ Caltex $_{i t}+\beta_{9}$ Policy $_{t}^{*}$ Caltex $_{i t} *$ Black $_{i}$

$+\beta_{10}$ Policy $_{t}^{*}$ Caltex $_{i t} *$ Hispanic $_{i}+$ Year $_{t}+X_{i t}+v_{i t}$

where black is a dummy variable equal to one if the individual is black and zero otherwise, Hispanic is a dummy variable equal to one if the individual is of non-black, Hispanic ethnicity, Caltex is a dummy variable equal to one if the individual lived in either California or Texas, Policy is defined as observations occurring in 1996 or beyond, and $v_{i t}$ is the error term. ${ }^{16} X_{i t}$ is a vector of individual and family characteristics that includes a dummy variable for female, birth order of the child, age of the child in months and age-squared, highest grade achieved by the mother, a dummy variable for urban equal to one if the child's residence is classified as an urban area within the NLSY data, the grade of the child and grade-squared, and the marital status of the mother. To account for year-to-year shocks a vector of year dummy variables were also included with the initial year omitted to serve as the base year.

Marginal effects are presented in table 2. Column one shows results for the full sample of children in grades three to eight. Columns two and three show results from the full sample but omitting one of the policy states. This was done to check if results are robust to each state individually. Columns four to six show results by grade group. Overall, the results show a highly significant, negative impact on expectations for black children in grades five to eight that are robust to both states individually. No significant results are found for third and fourth graders.

\subsection{Parental Involvement}

\footnotetext{
${ }^{16}$ As per Bertrand et al. (2002), robust standard errors were calculated clustered around individual states. This is followed throughout all analyses in this study.
} 
The responses to how often the parents check homework, how often the parents help with homework, and how often the mother reads to the child allow for a variety of possible responses regarding parental behavior. To take advantage of this, an ordered probit model is used to estimate the possible effects of the policy changes on these activities.

$\operatorname{Prob}\left(\right.$ Involvement $\left._{i t}=j\right)=\operatorname{prob}\left(v_{j-1}<I_{i t}<v_{j}\right)$

where $j$ corresponds to the possible choice of responses, $I_{i t}$ is defined as

$I_{i t}=C+\beta_{1}$ Black $_{i}+\beta_{2}$ Hispanic $_{i}+\beta_{3}$ Caltex $_{\text {it }}+\beta_{4}$ Caltex $_{\text {it }} *$ Black $_{i}$

$+\beta_{5}$ Caltex $_{\text {it }} *$ Hispanic $_{i}+$ Year $_{t}+X_{i t}+v_{i t}$

for how often the parent checks on or helps with homework and

$I_{i t}=C+\beta_{1}$ Black $_{i}+\beta_{2}$ Hispanic $_{i}+\beta_{3}$ Caltex $_{i t}+\beta_{4}$ Caltex $_{i t} *$ Black $_{i}$

$+\beta_{5}$ Caltex $_{i t} *$ Hispanic $_{i}+\beta_{6}$ Policy $_{t} *$ Black $_{i}+\beta_{7}$ Policy $_{t} *$ Hispanic $_{i}$

$+\beta_{8}$ Policy $_{t} *$ Caltex $_{i t}+\beta_{9}$ Policy $_{t} *$ Caltex $_{i t} *$ Black $_{i}$

$+\beta_{10}$ Policy $_{t} *$ Caltex $_{\text {it }} *$ Hispanic $_{i}+$ Year $_{t}+X_{i t}+v_{i t}$

for how often the mother reads to the child, and $v_{j}$ are the cut points for the corresponding value of $j .{ }^{17}$ In each case there is a natural, hierarchical ordering to the responses given, although the distances between each value do not imply a cardinal ranking. As such the actual value of response is not relevant, only that higher valued responses correspond to greater levels of involvement among the parents.

The ordered-probit regression results are shown in Table 3. There are some interesting trends evident in the data for the frequency with which black parents check on or help with the homework of their child. Black parents of $3^{\text {rd }}$ to $6^{\text {th }}$ graders in California

\footnotetext{
${ }^{17}$ For how often the parents check homework and how often parents help with homework, $\mathrm{j}=(0=$ never, $1=$ less than once month, $2=1-2$ times a month, $3=1-2$ times a week, $4=$ almost every day, $5=$ every day). For how often the parent reads to the child, $\mathrm{j}=(1=$ never, $2=$ several times a year, $3=$ =several times a month, $4=$ once a week, $5=$ about 3 times a week, $6=$ =veryday).
} 
and Texas show strongly significant, negative results that are robust to both states. The youngest age group essentially shows no impact.

The results for how often black parents in California and Texas read to their child after the policy changes show a strongly negative result for two of the three age groups examined, both highly significant and robust to both states individually. These results are intriguing for two reasons. First, they include several years of observation both before and after the policy changes. Second, much of the current literature focuses on the impact of reading to children in the early years of childhood on the existing black-white skill gaps, thus finding significant results among this set of decision variables does provide a

more direct link between perceptions about future opportunities and the important early skill gaps that exist between races.

\subsection{Weekly Hours Spent on Homework}

Estimation on weekly hours spent doing homework using pooled, independent cross sections were done using the difference-in-differences estimator where the treatment groups are minority children (black and Hispanic) in California and Texas and the control group consisted of white children in California and Texas and children of all races and ethnicities in the rest of the U.S. The data were divided into two-year grade groups. This was done to account for the fact that time spent doing homework may vary considerable across grade levels.

Separate analyses were performed for each of the four measures: weekly hours spent doing homework at school, weekly hours spent doing homework outside of school, weekly hours spent doing math homework, and weekly hours spent doing writing homework. 
The underlying regression equation for weekly hours spent doing homework is:

Hours $_{i t}=C+\beta_{1}$ Black $_{i}+\beta_{2}$ Hispanic $_{i}+\beta_{3}$ Caltex $_{i t}+\beta_{4}$ Caltex $_{i t} *$ Black $_{i}$

$+\beta_{5}$ Caltex $_{i t} *$ Hispanic $_{i}+$ Year $_{t}+X_{i t}+v_{i t}$

where Hours it $_{\text {is }}$ the number of hours spent each week on homework for each of the four measures previously mentioned for individual $i$ in year $t$. Observations were omitted if the relevant measure of hours spent studying was missing in the data or if data was missing from one of the covariates used in each of the analyses.

When pooling two policy states together as a single treatment group there is always the possibility that a state specific effect could be driving the overall results. Results, therefore, are also reported using California and Texas independently relative to the rest of the country. There is also the issue of a lower bound on the number of hours spent studying each week. Approximately thirty percent of the sample reported zero hours each week. Using a linear model in this case may lead to negative predictions for hours studying, so the Tobit model is used for the estimation.

The results for hours spent doing homework are presented in tables 4 and 5 . Table 4 panel A provides results for the outcomes of interest, the difference-in-differences estimators Caltex $*$ Black and Caltex*Hispanic, for $7^{\text {th }}$ and $8^{\text {th }}$ graders. Column one shows results for the entire sample for all years 1996 to 2002. The results show that blacks in California and Texas study significantly less on all three measures of hours spent doing homework after school.

Columns two and three show results for California and Texas separately relative to the rest of the U.S. The California results are almost identical to those from the entire sample, while the Texas results show a slightly smaller effect and are insignificant for one of the three measures. Overall, these results suggest a negative effect on hours spent 
studying after school among $7^{\text {th }}$ and $8^{\text {th }}$ grade black children that is consistent across all measures, and appears to not be a state specific event.

In order to get a better sense of who is most affected by the policy changes I divide the sample into two groups based on mother's education with those with mothers having at least some college (13 years or greater) into one group and those with mothers having a high school degree or less in the other. The intuition being that children with mothers having more than a high school education may live in a household that is more informed about the policy changes and may be more likely to be considering college themselves. These results are shown in columns four and five of Table 4 and strongly support the above hypothesis with an even larger impact on black children of higher educated mothers, while the effect on children of lesser educated mothers are insignificant on two of the three after school measures.

The results for time spent studying at school show no significant impacts among the relevant variables for black children. A possible explanation being that time spent at school is more a product of the schools attended and less the result of choices made by the students themselves. This variable is included as a possible proxy for school effects.

In order to test whether the results on hours spent doing homework after school are simply the result of differences in the frequency of homework assigned by the teacher, I utilize child responses regarding how often their teacher assigns homework each week. I divide the data into two groups: those whose teacher assigns homework several times a week and those whose teacher assigns homework two or fewer times per week. Results, reported in panel B of table 4, are very strong for black children assigned homework several times per week and are robust across all three after school measures 
and both states. Results for the children with less frequent homework are generally negative, with more intermittent significant results. These results tend to support the argument that differences in the amount of homework assigned do not explain the disparities in hours spent studying among minorities in the affected states.

Table 5 shows the primary results for hours spent studying after school for all grade groups. The results show a consistently negative outcome among blacks, with eleven of the twelve measures for hours spent after school having negative coefficients, however, only six of the twelve are significant. The strongest results are among the oldest group tested which is consistent with the policy change used in the analysis given that it is the older children who are most likely to understand the policy and its possible implications. The significant results among the youngest group could perhaps be explained by the significant reductions in parental involvement prior to the child starting school, shown in table 3 panel C.

\section{Impact on Cognitive Achievement}

I use two methods to test the impact on cognitive achievement. First, I organize the data into independent cross-sections broken down by age group to compare test scores for groups of children of similar ages before and after the policy changes. Second, I arrange the data as a panel and analyze using an individual fixed effects model to look at changes in the growth rate of test scores for the same children as they age. In the analysis of test scores post-policy refers to the years 1998, 2000, and 2002, while prepolicy refers to all years prior. This is due to the obvious lag that should occur between changes in investment decisions and the impact on test scores.

\subsection{Independent Cross-Sections by Age Group}


Estimation for the cross-sectional analysis was done using the following equation:

Math $_{i t}=C+\beta_{1}$ Black $_{i}+\beta_{2}$ Hispanic $_{i}+\beta_{3}$ Caltex $_{i t}+\beta_{4}$ Policy $_{t} *$ Black $_{i}$

$+\beta_{5}$ Policy $_{t} *$ Hispanic $_{i}+\beta_{6}$ Caltex $_{i t} *$ Black $_{i}+\beta_{7}$ Caltex $_{i t} *$ Hispanic $_{i}$

$+\beta_{8}$ Policy $_{t} *$ Caltex $_{\text {it }}+\beta_{9}$ Policy $_{t} *$ Caltex $_{\text {it }} *$ Black $_{i}$

$+\beta_{10}$ Policy $_{t} *$ Caltex $_{\text {it }} *$ Hispanic $_{i}+$ Year $_{t}+X_{i t}+v_{i t}$

where $\mathrm{Math}_{i t}$ is the math score for individual $\mathrm{i}$ in year t, Policy is a dummy variable equal to one if the observation occurs in the post policy era $\left(1998,2000\right.$, or 2002), and $X_{i t}$ includes all variables previously defined with the addition of a control for the number of times the child has taken the test in previous years.

The empirical results from the estimation using the entire U.S. sample are presented in Table 6. Column one gives estimates for all age groups pooled together. Columns two to five show results for the two year age groupings.

The signs for all standard explanatory variables are consistent with a priori expectations. The coefficients of primary interest are presented in rows one and two. The coefficient on Policy*CT*Black is negative and significant at the $1 \%$ level for the all age group and two of the four two-year age groupings. The coefficients are also economically significant considering that the test has a score range of 0 to 84 points. For perspective, the mean test score for U.S. blacks in the post-policy era is 43.2, so a coefficient of 2.327 represents a reduction in test scores of approximately 5.3\% relative to blacks elsewhere. The coefficient for the thirteen and fourteen year old group of -6.379 implies an adjusted score that is approximately $12 \%$ lower than blacks elsewhere. Estimates for the effect on Hispanic children are insignificant for all specifications of the model tested. The Policy*Caltex variable captures the impact of the policy changes on whites in California and Texas. The coefficient is positive and significant for both the pooled group 
and the oldest age group. It appears, based on this, that possible concern over California and Texas whites being an adequate control group may be warranted since it violates the primary assumption that the control group be unaffected by the policy change. This adds to the importance of including whites and minorities elsewhere as an additional control group to help mitigate the effects of this problem. Additionally, the finding that whites in California and Texas were doing significantly better following the policy changes adds empirical support to the proposed theoretical foundation given that whites presumably perceived an increase in educational opportunities.

Figures 4 and 5 show math test score kernel density estimates derived from the regression residuals for thirteen and fourteen year olds. Figure 4 shows the density distribution for California and Texas blacks before and after the policy changes, illustrating a pretty clear shift to the left in the distribution for the post policy period. For comparison purposes, Figure 4 also shows the test score distribution for blacks living in unaffected states before and after the policy changes. There does appear to be slight gains for blacks elsewhere, but the groups much more closely resemble each other than what was found in the policy states. Figure 5 compares kernel density estimates for California and Texas blacks and whites before and after the policy changes. The figure shows that white children were performing better than blacks prior to the policy changes, however after the policy changes the gulf widened noticeably.

\subsubsection{Robustness}

In addition to the primary model I also examine a number of alternative specifications. The results, broken down by model specification and age group, are shown in table 7 with results from the primary model described in the previous section 
reproduced in row one for comparison purposes. Overall, the results for blacks are very consistent across all specifications and closely match those found among the investment variables discussed earlier in terms of age groups.

Rows two through ten include the same set of covariates as the main regressions presented in table 6 but alter the sample used. Row two looks at a model restricted to California and Texas only and omits the rest of the country as a comparison group. This specification is included to avoid possible unknown factors from other states that may be contributing to the significant results found in the main model.

Rows three and four show results for a model where each of the policy states are tested independently, omitting the other state from the sample. These specifications are included to address the possibility that events within a single state, either California or Texas, may be driving the overall results. It appears, based on these results, that the results from the main set of regressions reported in table 6 are not being driven by a single, state specific event since results are fairly similar for both models that exclude one of the policy states. The robustness of the results to the Texas only specification is also important because it suggests that results are not being entirely driven by the more expansive policy change that occurred in California.

Row five looks at a model that is restricted to blacks before and after the policy in the affected states relative to blacks elsewhere. This sample specification suggests that the inclusion of California and Texas whites are not driving the results and that blacks in California and Texas had a reduction in their human capital development relative to blacks elsewhere. 
Row six shows results for a model that omits the year 1996 from the sample. The policies in question were passed in 1996 but not enacted until 1997. Given that the outcome measure of interest is a math test score, it is expected that there should be a lag between possible changes in minority behavior and the subsequent impact on test scores. As a result, 1998 was selected as the initial post-policy year. There is, however, some ambiguity as to whether 1996 should be classified as pre-policy. The results show very little change for a sample with 1996 omitted.

Rows seven to ten show results that include states omitted for various reasons from the main model tested. The remaining rows add additional covariates to the basic set used in the main model, such as mother's AFQT, net family income, marital status of the mother, and family size. Adding in additional covariates ultimately reduces sample sizes due to missing observations, so the more basic set of covariates is used in the primary analyses. The results, however, show that very little changes once the additional covariates are added to the model.

The sample was also divided into two groups, those with mothers who had thirteen or more years of education and those having twelve or fewer years. These results are shown in Table 8 . The results show a large and significant negative impact of the policy on California and Texas blacks in the high mother's education group for three of the five age groupings and negative coefficients on all of them. The low mother's education group has a much smaller effect and is significant for only the eldest group. This again matches closely to the results found in table 4, with strongest results occurring among children whose mother had at least some college and among the eldest age group.

\subsection{Impact on the Growth Rate of Test Scores}


In order to examine the rate of growth in math scores as children age I organize the data as a panel of same individuals across time and estimate using an individual fixed effects model. I estimate the model using three sets of panel data: a sample that includes all races but is restricted to California and Texas only, a sample that includes all races for the entire U.S., and a U.S. sample that is restricted to only blacks. In all cases I restrict the samples to individuals who had valid math test scores in both 1996 and 2000.

The estimating equation for the model that includes the entire U.S. is:

$$
\begin{aligned}
& \text { Math }_{i t}=C+\beta_{1} \text { Policy }_{t}+\beta_{2} \text { Policy }_{t} * \text { Black }_{i}+\beta_{3} \text { Policy }_{t} * \text { Hispanic }_{i} \\
& +\beta_{4} \text { Policy }_{t} * \text { Caltex }_{i}+\beta_{5} \text { Policy }_{t} * \text { Caltex }_{i} * \text { Black }_{i} \\
& +\beta_{6} \text { Policy }_{t} * \text { Caltex }_{i} * \text { Hispanic }_{i}+X_{i t}+a_{i}+u_{i t}
\end{aligned}
$$

where $X_{i t}$ is a vector of observable time varying individual characteristics, $a_{i}$ includes the unobservable individual characteristics that are constant over time.

Results for the individual fixed effects estimation are presented in Table 9. Column two reports results for the sample that includes the entire U.S. Results for the model with data restricted to California and Texas only are shown in column three. Column four shows results from a U.S. sample restricted to only blacks.

The coefficient for the effect of the policy on blacks in California and Texas from the U.S. model, Policy*CalTex*Black from column one, is -7.092 and significant at the $1 \%$ level. The other sample specifications also show highly significant results for blacks in California and Texas (Policy*Black from column two and Policy*CalTex from column three). Column 1 of table 9 shows the growth rate for a panel beginning in 1990 and ending in 1994, prior to the policy changes. No significant differences among blacks in California and Texas are found, suggesting no pre-trend existed. Figure 6 shows the rate 
of growth in math test scores taken from the regression residuals for various groups. The distribution for California and Texas blacks is clearly to the left of all others.

\section{Conclusion and Discussion}

Recent literature has demonstrated the importance of white-minority skill gaps in explaining wage differentials between races. It has also been shown that these skill gaps are present at very early ages and persist through adulthood. Given the significant role that skill gaps have in explaining wage inequality it is important to better understand the causes of these gaps in order to help make informed policy decisions that can be effective at remedying this issue. In this paper I have attempted to empirically analyze one potential cause for the existence of skill gaps. Namely that minorities perceive a world in which they expect to have fewer opportunities than whites and respond to this by investing less in human capital development when young.

Using changes in the affirmative action policies regarding admissions into colleges and universities that occurred in California and Texas during the mid 1990s, I examine a number of child and parental human capital investment variables to see if the policy changes resulted in changes in minority behavior. I find fairly consistent, negative results among child input variables for black children and parents in the affected states.

I also find a highly significant, negative impact on math test scores for black children that is consistent across sample and model specifications. The results are strongest among older children and children whose mother had more than twelve years of education. More importantly, these results closely match those found for investment variables. Older children were found to have spent significantly less time studying, which corresponds closely to drops in test scores for children in this age group using a much 
longer period of data. The significant drop in test scores found among younger children also corresponds closely to changes in parental inputs among this age group. Hispanic children show more ambiguous results.

The stronger results for black children than for Hispanic children are consistent with three important factors. First, public attention regarding economic and social disadvantage in the United States appears to be significantly more focused on the plight of blacks than any other minority group. As a result, it is plausible that perceptions about fewer opportunities of all types for blacks is more ingrained in our society than it is for other minority groups. Second, exit polling data from the 1996 election regarding Proposition 209 in California suggested that Hispanics were much more divided on the issue than were blacks. Finally, the black-white skill gap is marginally larger than the Hispanic-white gap. The results are consistent with negative expectations possibly affecting both groups, but affecting blacks in a more significant fashion.

It is possible that the effects found could be the result of concurrent policy changes or events unrelated to the ending of affirmative action. It is important to note, however, that any policy that affects children of all races equally would be controlled for in both the difference-in-differences or fixed effects estimations. What would be required are policies that differentially affect minorities. Further, given that stronger results are found for black children than for Hispanic children, any concurrent policy changes would have to differentially affect black children in a negative fashion in order to produce these results. Certainly a case could be made that school funding changes may differentially affect inner-city schools and therefore have a greater impact, positive or negative, on 
minority children. In many cases, however, blacks and Hispanics go to the same schools and should be affected equally by such an outcome.

Overall, the results do suggest that negative future expectations are playing a role in the human capital development of black children. Additionally, the results suggest that affirmative action programs may play a role in skill levels between whites and blacks beyond the intended goals of such policies. At the very least, it appears that ending affirmative action did not result in an increase in minority human capital investment. 


\section{References}

Alvarez, R. Michael and Lisa Garcia Bedolla, “The Revolution against Affirmative Action in California: Racism, Economics, and Proposition 209,” State Politics and Policy Quarterly 4:1 (2004), 1-17.

Bertrand, Marianne, E. Duflo, and S. Mullainathan, "How Much Should We Trust Differences-In-Differences Estimates?” The Quarterly Journal of Economics 119:1 (2004), 249-75.

Brown, Susan K. and Charles Hirschman, “The End of Affirmative Action in Washington State and Its Impact on the Transition from High School to College,” Sociology of Education 79 (2006), 106-130.

Card, David and Alan Krueger, "Would the Elimination of Affirmative Action Affect Highly Qualified Minority Applicants? Evidence from California and Texas,” Industrial and Labor Relations Review 58:3 (2005), 416-34.

Carneiro, P., J. Heckman, and D. Masterov, “Labor Market Discrimination and Racial Differences in Premarket Factors,” Journal of Law and Economics 48:1 (2005), 139.

Dickson, Lisa M., "Does ending affirmative action in college admissions lower the percent of minority students applying to college?” Economics of Education Review 25:1 (2006), 109-119.

Fryer, Roland and Steven Levitt, "Understanding the black-white test score gap in the first two years of school,"Review of Economics and Statistics 86:2(2004),447-64.

Fryer, Roland and Steven Levitt, “The Black-White Test Score Gap Through Third Grade,” Forthcoming American Law and Economic Review. 
Long, Mark C., “College applications and the effect of affirmative action,” Journal of Econometrics 121 (2004a), 319-342.

Long, Mark C., "Race and College Admissions: An Alternative to Affirmative Action?” Review of Economics and Statistics 86:4 (2004b), 1020-33.

Long, Mark C., (2007). “Affirmative Action and Its Alternatives in Public Universities: What Do We Know?” Public Administration Review, 67(2): 315-330.

Lundberg, Shelly and Richard Startz, "Private Discrimination and Social Intervention in Competitive Labor Markets,” American Economic Review 73 (1983), 340-347.

Lundberg, Shelly and Richard Startz, "Inequality and Race: Models and Policy,” In Kenneth Arrow, Samuel Bowles, and Steven Durlauf (Eds.), Meritocracy and Economic Inequality (Princeton, New Jersey: Princeton University Press, 2000).

Neal, Derek and William Johnson, “The Role of Premarket Factors in Black-White Wage Differences,” The Journal of Political Economy 104:5 (1996), 869-895.

Neal, Derek, "Why has the Black-White Skill Convergence Stopped,” NBER working paper no. 11090 (2005).

Todd Petra and Kenneth Wolpin, "The Production of Cognitive Achievement in Children: Home, School and Racial Test Score Gaps,” Journal of Human Capital 1 (2007), 91-136. 
Table 1: Summary Statistics - Mean (Standard Deviation)

\begin{tabular}{ccccccc}
\hline & $\begin{array}{c}\text { CA \& Tex } \\
\text { Blacks }\end{array}$ & $\begin{array}{c}\text { U.S. } \\
\text { Blacks }\end{array}$ & $\begin{array}{c}\text { CA \& Tex } \\
\text { Hispanics }\end{array}$ & $\begin{array}{c}\text { U.S. } \\
\text { Hispanics }\end{array}$ & $\begin{array}{c}\text { CA \& Tex } \\
\text { Whites }\end{array}$ & $\begin{array}{c}\text { U.S. } \\
\text { Whites }\end{array}$ \\
\hline Observations & 798 & 4859 & 2081 & 1534 & 1055 & 7090 \\
Birth Order & 1.89 & 2.03 & 2.00 & 1.90 & 1.75 & 1.72 \\
& $(0.99)$ & $(1.16)$ & $(1.10)$ & $(0.98)$ & $(1.00)$ & $(0.88)$ \\
Family Size & 4.44 & 4.60 & 4.96 & 4.51 & 4.31 & 4.38 \\
(1.43) & $(1.67)$ & $(1.56)$ & $(1.41)$ & $(1.40)$ & $(1.19)$ \\
Mother's Age at & 22.43 & 22.79 & 23.45 & 23.34 & 24.18 & 24.56 \\
Birth & $(4.16)$ & $(4.29)$ & $(4.17)$ & $(4.15)$ & $(4.25)$ & $(4.34)$ \\
Mother's High & 12.83 & 12.32 & 11.58 & 11.73 & 13.04 & 12.94 \\
Grade & $(1.44)$ & $(1.98)$ & $(2.83)$ & $(2.46)$ & $(2.31)$ & $(2.17)$ \\
Mother's AFQT & 18.11 & 19.65 & 21.14 & 25.96 & 48.41 & 49.51 \\
\% Female & $(16.14)$ & $(17.89)$ & $(19.86)$ & $(22.59)$ & $(26.10)$ & $(26.14)$ \\
\% Two Parent & $49.7 \%$ & $51.7 \%$ & $48.8 \%$ & $46.1 \%$ & $49.7 \%$ & $49.7 \%$ \\
Household & $40.8 \%$ & $34.8 \%$ & $66.8 \%$ & $54.4 \%$ & $74.7 \%$ & $77.1 \%$ \\
\% Urban & & & & & $76.7 \%$ & $61.9 \%$ \\
\hline
\end{tabular}


Table 2: Probit Marginal Effects - Child Expects to Attend College

\begin{tabular}{|c|c|c|c|c|c|c|}
\hline & $\begin{array}{l}\text { (1) } \\
\text { All }\end{array}$ & $\begin{array}{l}\text { (2) } \\
\text { Cal }\end{array}$ & $\begin{array}{l}\text { (3) } \\
\text { Tex }\end{array}$ & $\begin{array}{c}(4) \\
3 \& 4\end{array}$ & $\begin{array}{c}(5) \\
5 \& 6\end{array}$ & $\begin{array}{c}(6) \\
7 \& 8\end{array}$ \\
\hline Policy*CalTex*Black & $\begin{array}{l}-0.078^{* * *} \\
(0.029)\end{array}$ & $\begin{array}{l}-0.126 * * * \\
(0.026)\end{array}$ & $\begin{array}{l}-0.100 \text { *** } \\
(0.026)\end{array}$ & $\begin{array}{l}0.027 \\
(0.080)\end{array}$ & $\begin{array}{l}-0.105^{* *} \\
(0.051)\end{array}$ & $\begin{array}{l}-0.110^{* * *} \\
(0.041)\end{array}$ \\
\hline Policy*CalTex*Hispanic & $\begin{array}{l}-0.009 \\
(0.034)\end{array}$ & $\begin{array}{l}0.015 \\
(0.035)\end{array}$ & $\begin{array}{l}-0.007 \\
(0.033)\end{array}$ & $\begin{array}{l}0.171^{*} \\
(0.094)\end{array}$ & $\begin{array}{l}-0.035 \\
(0.037)\end{array}$ & $\begin{array}{l}0.002 \\
(0.066)\end{array}$ \\
\hline Policy & $\begin{array}{l}0.041 * * * \\
(0.011)\end{array}$ & $\begin{array}{l}0.040 * * * \\
(0.011)\end{array}$ & $\begin{array}{l}0.040 * * * \\
(0.011)\end{array}$ & $\begin{array}{l}0.004 \\
(0.033)\end{array}$ & $\begin{array}{l}0.054 * * * \\
(0.016)\end{array}$ & $\begin{array}{l}0.035 \\
(0.026)\end{array}$ \\
\hline CalTex & $\begin{array}{l}0.007 \\
(0.025)\end{array}$ & $\begin{array}{l}-0.021 * \\
(0.012)\end{array}$ & $\begin{array}{l}0.045^{* * *} \\
(0.017)\end{array}$ & $\begin{array}{l}0.001 \\
(0.031)\end{array}$ & $\begin{array}{l}0.017 \\
(0.025)\end{array}$ & $\begin{array}{l}-0.005 \\
(0.041)\end{array}$ \\
\hline Black & $\begin{array}{l}-0.070 * * * \\
(0.019)\end{array}$ & $\begin{array}{l}-0.070 * * * \\
(0.019)\end{array}$ & $\begin{array}{l}-0.073 * * * \\
(0.019)\end{array}$ & $\begin{array}{l}-0.089 * * \\
(0.041)\end{array}$ & $\begin{array}{l}-0.083 * * * \\
(0.026)\end{array}$ & $\begin{array}{l}-0.046 \\
(0.029)\end{array}$ \\
\hline Policy*CalTex & $\begin{array}{l}0.021 \\
(0.020)\end{array}$ & $\begin{array}{l}0.010 \\
(0.013)\end{array}$ & $\begin{array}{l}0.069 * * * \\
(0.013)\end{array}$ & $\begin{array}{l}-0.099 * * \\
(0.040)\end{array}$ & $\begin{array}{l}0.045 \\
(0.039)\end{array}$ & $\begin{array}{l}0.060 \\
(0.038)\end{array}$ \\
\hline Policy*Black & $\begin{array}{l}0.048^{*} \\
(0.026)\end{array}$ & $\begin{array}{l}0.048 * \\
(0.026)\end{array}$ & $\begin{array}{l}0.047^{*} \\
(0.025)\end{array}$ & $\begin{array}{l}0.139 * * * \\
(0.049)\end{array}$ & $\begin{array}{l}0.023 \\
(0.032)\end{array}$ & $\begin{array}{l}0.036 \\
(0.038)\end{array}$ \\
\hline CalTex*Black & $\begin{array}{l}-0.001 \\
(0.046)\end{array}$ & $\begin{array}{l}0.071^{* * *} \\
(0.020)\end{array}$ & $\begin{array}{l}-0.061 * * * \\
(0.021)\end{array}$ & $\begin{array}{l}-0.017 \\
(0.046)\end{array}$ & $\begin{array}{l}0.001 \\
(0.055)\end{array}$ & $\begin{array}{l}0.002 \\
(0.063)\end{array}$ \\
\hline Hispanic & $\begin{array}{l}0.013 \\
(0.030)\end{array}$ & $\begin{array}{l}0.015 \\
(0.030)\end{array}$ & $\begin{array}{l}0.011 \\
(0.030)\end{array}$ & $\begin{array}{l}0.020 \\
(0.047)\end{array}$ & $\begin{array}{l}0.019 \\
(0.340)\end{array}$ & $\begin{array}{l}-0.007 \\
(0.066)\end{array}$ \\
\hline Policy*Hispanic & $\begin{array}{l}-0.009 \\
(0.034)\end{array}$ & $\begin{array}{l}-0.008 \\
(0.034)\end{array}$ & $\begin{array}{l}-0.009 \\
(0.033)\end{array}$ & $\begin{array}{l}-0.036 \\
(0.082)\end{array}$ & $\begin{array}{l}-0.026 \\
(0.036)\end{array}$ & $\begin{array}{l}0.031 \\
(0.054)\end{array}$ \\
\hline CalTex*Hispanic & $\begin{array}{l}-0.030 \\
(0.039)\end{array}$ & $\begin{array}{l}0.005 \\
(0.030)\end{array}$ & $\begin{array}{l}-0.075^{* *} \\
(0.029)\end{array}$ & $\begin{array}{l}0.003 \\
(0.049)\end{array}$ & $\begin{array}{l}-0.043 \\
(0.053)\end{array}$ & $\begin{array}{l}-0.021 \\
(0.081)\end{array}$ \\
\hline Mother’s High Grade & $\begin{array}{l}0.032 * * * \\
(0.003)\end{array}$ & $\begin{array}{l}0.034 * * * \\
(0.003)\end{array}$ & $\begin{array}{l}0.032 * * * \\
(0.003)\end{array}$ & $\begin{array}{l}0.035^{* * *} \\
(0.005)\end{array}$ & $\begin{array}{l}0.027 * * * \\
(0.003)\end{array}$ & $\begin{array}{l}0.038 * * * \\
(0.004)\end{array}$ \\
\hline Female & $\begin{array}{l}0.042 * * * \\
(0.009)\end{array}$ & $\begin{array}{l}0.046^{* * *} \\
(0.009)\end{array}$ & $\begin{array}{l}0.044 * * * \\
(0.009)\end{array}$ & $\begin{array}{l}0.057 * * \\
(0.023)\end{array}$ & $\begin{array}{l}0.030 * * \\
(0.013)\end{array}$ & $\begin{array}{l}0.047 * * * \\
(0.015)\end{array}$ \\
\hline Birth Order & $\begin{array}{l}-0.013^{* * *} \\
(0.005)\end{array}$ & $\begin{array}{l}-0.013^{* * *} \\
(0.005)\end{array}$ & $\begin{array}{l}-0.017 * * \\
(0.005)\end{array}$ & $\begin{array}{l}0.010 \\
(0.010)\end{array}$ & $\begin{array}{l}-0.011^{*} \\
(0.006)\end{array}$ & $\begin{array}{l}-0.025 * * * \\
(0.005)\end{array}$ \\
\hline Mother Married & $\begin{array}{l}0.045^{* * *} \\
(0.012)\end{array}$ & $\begin{array}{l}0.048 * * * \\
(0.011)\end{array}$ & $\begin{array}{l}0.037 * * * \\
(0.011)\end{array}$ & $\begin{array}{l}0.075 * * * \\
(0.023)\end{array}$ & $\begin{array}{l}0.018 \\
(0.012)\end{array}$ & $\begin{array}{l}0.066 * * * \\
(0.017)\end{array}$ \\
\hline Urban & $\begin{array}{l}0.018^{*} \\
(0.010)\end{array}$ & $\begin{array}{l}0.021 * * \\
(0.010)\end{array}$ & $\begin{array}{l}0.017 \\
(0.010)\end{array}$ & $\begin{array}{l}0.014 \\
(0.024)\end{array}$ & $\begin{array}{l}0.029 * * \\
(0.013)\end{array}$ & $\begin{array}{l}0.007 \\
(0.013)\end{array}$ \\
\hline Observations & 8752 & 7953 & 7647 & 1639 & 4088 & 3025 \\
\hline
\end{tabular}

Robust standard errors in parentheses.

* significant at $10 \%$; ** significant at $5 \%$; *** significant at $1 \%$. 
Table 3: Parental Inputs - Ordered Probits

Panel A: How Often Parents Check Homework

\begin{tabular}{|c|c|c|c|c|c|c|}
\hline & \multicolumn{3}{|c|}{ CalTex*Black } & \multicolumn{3}{|c|}{$\underline{\text { CalTex*Hispanic }}$} \\
\hline & $\begin{array}{l}\text { (1) } \\
\text { (All) }\end{array}$ & $\begin{array}{c}(2) \\
(\mathrm{Cal}) \\
\end{array}$ & $\begin{array}{c}(3) \\
\text { (Tex) }\end{array}$ & $\begin{array}{c}\text { (4) } \\
\text { (All) }\end{array}$ & $\begin{array}{c}(5) \\
(\mathrm{Cal})\end{array}$ & $\begin{array}{c}(6) \\
(\mathrm{Tex}) \\
\end{array}$ \\
\hline Grades 5 \& 6 & $\begin{array}{l}-0.316 \\
(0.096)^{* * *}\end{array}$ & $\begin{array}{l}-0.443 \\
(0.075)^{* * *}\end{array}$ & $\begin{array}{l}-0.269 \\
(0.080)^{* * *}\end{array}$ & $\begin{array}{l}0.116 \\
(0.163)\end{array}$ & $\begin{array}{l}0.261 \\
(0.096)^{* * *}\end{array}$ & $\begin{array}{l}-0.127 \\
(0.093)\end{array}$ \\
\hline Grades 3 \& 4 & $\begin{array}{l}-0.294 \\
(0.091)^{* * *}\end{array}$ & $\begin{array}{l}-0.228 \\
(0.079)^{* * *}\end{array}$ & $\begin{array}{l}-0.366 \\
(0.089)^{* * *}\end{array}$ & $\begin{array}{l}-0.133 \\
(0.142)\end{array}$ & $\begin{array}{l}-0.017 \\
(0.108)\end{array}$ & $\begin{array}{l}-0.299 \\
(0.108)^{* * *}\end{array}$ \\
\hline Grades $1 \& 2$ & $\begin{array}{l}0.309 \\
(0.232)\end{array}$ & $\begin{array}{l}0.597 \\
(0.085)^{* * *}\end{array}$ & $\begin{array}{l}-0.018 \\
(0.094)\end{array}$ & $\begin{array}{l}0.088 \\
(0.208)\end{array}$ & $\begin{array}{l}0.268 \\
(0.147)^{*}\end{array}$ & $\begin{array}{l}-0.157 \\
(0.152)\end{array}$ \\
\hline
\end{tabular}

Panel B: How Often Parents Help with Homework

\begin{tabular}{|c|c|c|c|c|c|c|}
\hline & \multicolumn{3}{|c|}{ CalTex*Black } & \multicolumn{3}{|c|}{ CalTex*Hispanic } \\
\hline & $\begin{array}{l}\text { (1) } \\
\text { (All) }\end{array}$ & $\begin{array}{c}(2) \\
(\mathrm{Cal})\end{array}$ & $\begin{array}{c}(3) \\
\text { (Tex) }\end{array}$ & $\begin{array}{l}\text { (4) } \\
\text { (All) }\end{array}$ & $\begin{array}{c}\text { (5) } \\
\text { (Cal) }\end{array}$ & $\begin{array}{c}(6) \\
\text { (Tex) }\end{array}$ \\
\hline Grades 5 \& 6 & $\begin{array}{l}-0.302 \\
(0.103)^{* * *}\end{array}$ & $\begin{array}{l}-0.348 \\
(0.094)^{* * *}\end{array}$ & $\begin{array}{l}-0.217 \\
(0.091)^{* *}\end{array}$ & $\begin{array}{l}-0.011 \\
(0.112)\end{array}$ & $\begin{array}{l}-0.027 \\
(0.113)\end{array}$ & $\begin{array}{l}0.019 \\
(0.111)\end{array}$ \\
\hline Grades $3 \& 4$ & $\begin{array}{l}-0.333 \\
(0.143)^{* *}\end{array}$ & $\begin{array}{l}-0.560 \\
(0.071)^{* * *}\end{array}$ & $\begin{array}{l}-0.228 \\
(0.081)^{* * *}\end{array}$ & $\begin{array}{l}0.059 \\
(0.139)\end{array}$ & $\begin{array}{l}0.122 \\
(0.131)\end{array}$ & $\begin{array}{l}-0.049 \\
(0.125)\end{array}$ \\
\hline Grades $1 \& 2$ & $\begin{array}{l}-0.022 \\
(0.099)\end{array}$ & $\begin{array}{l}-0.114 \\
(0.071)\end{array}$ & $\begin{array}{l}0.088 \\
(.0700)\end{array}$ & $\begin{array}{l}0.217 \\
(0.110)^{* *}\end{array}$ & $\begin{array}{l}0.235 \\
(0.109)^{* *}\end{array}$ & $\begin{array}{l}0.158 \\
(0.105)\end{array}$ \\
\hline \multicolumn{7}{|c|}{ Panel C: How often Mother Reads to Child } \\
\hline & \multicolumn{3}{|c|}{ Policy*CalTex*Black } & \multicolumn{3}{|c|}{ Policy*CalTex*Hispanic } \\
\hline & $\begin{array}{l}(1) \\
\text { (All) } \\
\end{array}$ & $\begin{array}{c}(2) \\
(\mathrm{Cal}) \\
\end{array}$ & $\begin{array}{c}(3) \\
(\text { Tex }) \\
\end{array}$ & $\begin{array}{l}(4) \\
\text { (All) } \\
\end{array}$ & $\begin{array}{c}(5) \\
(\mathrm{Cal}) \\
\end{array}$ & $\begin{array}{l}\text { (6) } \\
\text { (Tex) }\end{array}$ \\
\hline Ages 6 to 9 & $\begin{array}{l}-0.255 \\
(0.084)^{* * *}\end{array}$ & $\begin{array}{l}-0.313 \\
(0.058)^{* * *}\end{array}$ & $\begin{array}{l}-0.133 \\
(.067)^{* *}\end{array}$ & $\begin{array}{l}0.028 \\
(0.143)\end{array}$ & $\begin{array}{l}0.044 \\
(0.142)\end{array}$ & $\begin{array}{l}0.021 \\
(0.146)\end{array}$ \\
\hline Ages 3 to 5 & $\begin{array}{l}0.221 \\
(0.282)\end{array}$ & $\begin{array}{l}0.557 \\
(0.100)^{* * *}\end{array}$ & $\begin{array}{l}-0.184 \\
(0.093)^{* *}\end{array}$ & $\begin{array}{l}0.043 \\
(0.161)\end{array}$ & $\begin{array}{l}0.076 \\
(0.157)\end{array}$ & $\begin{array}{l}-0.060 \\
(0.153)\end{array}$ \\
\hline Ages 0 to 2 & $\begin{array}{l}-0.646 \\
(0.215)^{* * *}\end{array}$ & $\begin{array}{l}-0.362 \\
(0.093)^{* * *}\end{array}$ & $\begin{array}{l}-0.900 \\
(0.090)^{* * *}\end{array}$ & $\begin{array}{l}-0.023 \\
(0.220)\end{array}$ & $\begin{array}{l}-0.140 \\
(0.184)\end{array}$ & $\begin{array}{l}0.270 \\
(0.199)\end{array}$ \\
\hline
\end{tabular}

Robust standard errors in parentheses.

* significant at $10 \%$; ** significant at $5 \%$; *** significant at $1 \%$.

Regression covariates also included mother’s high grade, gender, birth order, marital status of mother, urban, grade, age, and year. 
Table 4: Tobit Grades 7 \& 8 - Weekly Hours Spent on Homework

\begin{tabular}{|c|c|c|c|c|c|}
\hline Panel A: Full Sample & $\begin{array}{l}\text { (1) } \\
\text { (All) }\end{array}$ & $\begin{array}{l}(2) \\
(\mathrm{Cal})\end{array}$ & $\begin{array}{l}(3) \\
(\mathrm{Tex})\end{array}$ & $\begin{array}{c}\text { (4) } \\
\text { (High) }\end{array}$ & $\begin{array}{c}(5) \\
\text { (Low) }\end{array}$ \\
\hline \multicolumn{6}{|l|}{ CalTex*Black } \\
\hline $\begin{array}{l}\text { Hours After School Math Homework } \\
\text { Mother Reported }\end{array}$ & $\begin{array}{l}-1.854 * * * \\
(0.542)\end{array}$ & $\begin{array}{l}-2.375^{* * *} \\
(0.257)\end{array}$ & $\begin{array}{l}-0.795 * * * \\
(0.236)\end{array}$ & $\begin{array}{l}-2.124 * * * \\
(0.385)\end{array}$ & $\begin{array}{l}-1.578^{*} \\
(0.875)\end{array}$ \\
\hline $\begin{array}{l}\text { Hours After School Writing Homework } \\
\text { Mother Reported }\end{array}$ & $\begin{array}{l}-1.478 * \\
(0.805)\end{array}$ & $\begin{array}{l}-2.409 * * * \\
(0.272)\end{array}$ & $\begin{array}{l}0.082 \\
(0.256)\end{array}$ & $\begin{array}{l}-2.099 * * * \\
(0.478)\end{array}$ & $\begin{array}{l}-0.944 \\
(1.229)\end{array}$ \\
\hline $\begin{array}{l}\text { Hours After School Homework } \\
\text { Child Reported }\end{array}$ & $\begin{array}{l}-1.745^{* * *} \\
(0.421)\end{array}$ & $\begin{array}{l}-1.900 * * * \\
(0.327)\end{array}$ & $\begin{array}{l}-0.868 * * * \\
(0.317)\end{array}$ & $\begin{array}{l}-3.042 * * * \\
(0.608)\end{array}$ & $\begin{array}{l}-0.531 \\
(0.834)\end{array}$ \\
\hline $\begin{array}{l}\text { Hours In School Homework } \\
\text { Child Reported }\end{array}$ & $\begin{array}{l}0.002 \\
(0.300)\end{array}$ & $\begin{array}{l}0.024 \\
(0.290)\end{array}$ & $\begin{array}{l}-0.233 \\
(0.287)\end{array}$ & $\begin{array}{l}-0.784 \\
(0.724)\end{array}$ & $\begin{array}{l}0.273 \\
(0.679)\end{array}$ \\
\hline \multicolumn{6}{|l|}{ CalTex*Hispanic } \\
\hline $\begin{array}{l}\text { Hours After School Math Homework } \\
\text { Mother Reported }\end{array}$ & $\begin{array}{l}-1.074 * * * \\
(0.241)\end{array}$ & $\begin{array}{l}-1.040 * * * \\
(0.243)\end{array}$ & $\begin{array}{l}-0.824 * * * \\
(0.239)\end{array}$ & $\begin{array}{l}-1.104 * * \\
(0.476)\end{array}$ & $\begin{array}{l}-1.110^{* * *} \\
(0.277)\end{array}$ \\
\hline $\begin{array}{l}\text { Hours After School Writing Homework } \\
\text { Mother Reported }\end{array}$ & $\begin{array}{l}-0.885^{* *} \\
(0.392)\end{array}$ & $\begin{array}{l}-1.143 * * * \\
(0.253)\end{array}$ & $\begin{array}{l}-0.017 \\
(0.249)\end{array}$ & $\begin{array}{l}-1.371 * * * \\
(0.482)\end{array}$ & $\begin{array}{l}-0.618 \\
(0.503)\end{array}$ \\
\hline $\begin{array}{l}\text { Hours After School Homework } \\
\text { Child Reported }\end{array}$ & $\begin{array}{l}-0.792 \\
(0.483)\end{array}$ & $\begin{array}{l}-0.800 \\
(0.495)\end{array}$ & $\begin{array}{l}-0.463 \\
(0.469)\end{array}$ & $\begin{array}{l}-1.552 * * \\
(0.691)\end{array}$ & $\begin{array}{l}-0.198 \\
(0.649)\end{array}$ \\
\hline $\begin{array}{l}\text { Hours In School Homework } \\
\text { Child Reported }\end{array}$ & $\begin{array}{l}0.197 \\
(0.391)\end{array}$ & $\begin{array}{l}0.145 \\
(0.393)\end{array}$ & $\begin{array}{l}0.254 \\
(0.396)\end{array}$ & $\begin{array}{l}-1.025 \\
(0.781)\end{array}$ & $\begin{array}{l}0.980^{*} \\
(0.532)\end{array}$ \\
\hline \multicolumn{6}{|c|}{ Panel B: California and Texas Blacks by Frequency of Homework Given by Teacher } \\
\hline \multicolumn{6}{|l|}{ Almost Every Day } \\
\hline $\begin{array}{l}\text { Hours After School Math Homework Mother } \\
\text { Reported }\end{array}$ & $\begin{array}{l}-2.271 * * * \\
(0.412)\end{array}$ & $\begin{array}{l}-2.470 * * * \\
(0.318)\end{array}$ & $\begin{array}{l}-1.374 * * * \\
(0.289)\end{array}$ & $\begin{array}{l}-2.272 * * * \\
(0.585)\end{array}$ & $\begin{array}{l}-2.163 * * * \\
(0.488)\end{array}$ \\
\hline $\begin{array}{l}\text { Hours After School Writing Homework } \\
\text { Mother Reported }\end{array}$ & $\begin{array}{l}-2.407 * * * \\
(0.562)\end{array}$ & $\begin{array}{l}-2.788 * * * \\
(0.354)\end{array}$ & $\begin{array}{l}-0.834 * * * \\
(0.313)\end{array}$ & $\begin{array}{l}-2.214^{* *} \\
(1.007)\end{array}$ & $\begin{array}{l}-2.734^{* * *} \\
(0.533)\end{array}$ \\
\hline $\begin{array}{l}\text { Hours After School Homework } \\
\text { Child Reported }\end{array}$ & $\begin{array}{l}-1.612 * * * \\
(0.345)\end{array}$ & $\begin{array}{l}-1.607 * * * \\
(0.347)\end{array}$ & $\begin{array}{l}-0.948 * * * \\
(0.343)\end{array}$ & $\begin{array}{l}-2.775 * * * \\
(0.773)\end{array}$ & $\begin{array}{l}-0.397 \\
(0.451)\end{array}$ \\
\hline $\begin{array}{l}\text { Hours In School Homework } \\
\text { Child Reported }\end{array}$ & $\begin{array}{l}-0.034 \\
(0.509)\end{array}$ & $\begin{array}{l}0.217 \\
(0.399)\end{array}$ & $\begin{array}{l}-1.155^{* * *} \\
(0.335)\end{array}$ & $\begin{array}{l}-0.902 \\
(0.690)\end{array}$ & $\begin{array}{l}0.419 \\
(1.154)\end{array}$ \\
\hline \multicolumn{6}{|l|}{ Less Than Twice a Week } \\
\hline $\begin{array}{l}\text { Hours After School Math Homework Mother } \\
\text { Reported }\end{array}$ & $\begin{array}{l}-0.890 \\
(0.699)\end{array}$ & $\begin{array}{l}-2.163 * * * \\
(0.364)\end{array}$ & $\begin{array}{l}-0.015 \\
(0.328)\end{array}$ & $\begin{array}{l}-1.423^{* *} \\
(0.581)\end{array}$ & $\begin{array}{l}-0.156 \\
(1.851)\end{array}$ \\
\hline $\begin{array}{l}\text { Hours After School Writing Homework } \\
\text { Mother Reported }\end{array}$ & $\begin{array}{l}-0.380 \\
(0.697)\end{array}$ & $\begin{array}{l}-2.247 * * * \\
(0.410)\end{array}$ & $\begin{array}{l}0.228 \\
(0.364)\end{array}$ & $\begin{array}{l}-2.093 * * * \\
(0.700)\end{array}$ & $\begin{array}{l}1.707 \\
(1.603)\end{array}$ \\
\hline $\begin{array}{l}\text { Hours After School Homework } \\
\text { Child Reported }\end{array}$ & $\begin{array}{l}-1.962^{* *} \\
(0.905)\end{array}$ & $\begin{array}{l}-4.195 * * * \\
(0.417)\end{array}$ & $\begin{array}{l}-0.945^{* *} \\
(0.439)\end{array}$ & $\begin{array}{l}-2.821 * * * \\
(0.652)\end{array}$ & $\begin{array}{l}-1.225 \\
(1.832)\end{array}$ \\
\hline $\begin{array}{l}\text { Hours In School Homework } \\
\text { Child Reported }\end{array}$ & $\begin{array}{l}0.198 \\
(0.467)\end{array}$ & $\begin{array}{l}-0.097 \\
(0.418)\end{array}$ & $\begin{array}{l}0.724^{*} \\
(0.385)\end{array}$ & $\begin{array}{l}-0.270 \\
(0.823)\end{array}$ & $\begin{array}{l}0.201 \\
(0.401)\end{array}$ \\
\hline
\end{tabular}

Robust Standard errors in parentheses.

* significant at $10 \%$; ** significant at $5 \%$; *** significant at $1 \%$.

Regression covariates also included mother's high grade, gender, birth order, marital status of mother, urban, grade, age, and year. 
Table 5: Tobit by Grade Group - Weekly Hours Spent on Homework

\begin{tabular}{|c|c|c|c|c|}
\hline & $\begin{array}{c}(1) \\
1 \& 2 \\
\end{array}$ & $\begin{array}{c}(2) \\
3 \& 4 \\
\end{array}$ & $\begin{array}{c}(3) \\
5 \& 6 \\
\end{array}$ & $\begin{array}{c}(4) \\
7 \& 8 \\
\end{array}$ \\
\hline \multicolumn{5}{|l|}{ CalTex*Black } \\
\hline Hours After School Math Homework Mother Reported & $\begin{array}{l}-0.074 \\
(0.309)\end{array}$ & $\begin{array}{l}-0.547 * * \\
(0.233)\end{array}$ & $\begin{array}{l}0.036 \\
(0.331)\end{array}$ & $\begin{array}{l}-1.854 * * * \\
(0.542)\end{array}$ \\
\hline Hours After School Writing Homework Mother Reported & $\begin{array}{l}-0.610^{*} \\
(0.364)\end{array}$ & $\begin{array}{l}-0.637 \\
(0.463)\end{array}$ & $\begin{array}{l}-0.229 \\
(0.574)\end{array}$ & $\begin{array}{l}-1.478^{*} \\
(0.805)\end{array}$ \\
\hline Hours After School Homework Child Reported & $\begin{array}{l}-1.655^{* * *} \\
(0.284)\end{array}$ & $\begin{array}{l}-0.676 \\
(0.458)\end{array}$ & $\begin{array}{l}-0.363 \\
(0.958)\end{array}$ & $\begin{array}{l}-1.745 * * * \\
(0.421)\end{array}$ \\
\hline $\begin{array}{l}\text { Hours In School Homework } \\
\text { Child Reported }\end{array}$ & $\begin{array}{l}-0.233 \\
(0.391)\end{array}$ & $\begin{array}{l}0.989 \\
(1.124)\end{array}$ & $\begin{array}{l}1.037 * * \\
(0.424)\end{array}$ & $\begin{array}{l}0.002 \\
(0.300)\end{array}$ \\
\hline \multicolumn{5}{|l|}{ CalTex*Hispanic } \\
\hline Hours After School Math Homework Mother Reported & $\begin{array}{l}0.217 \\
(0.518)\end{array}$ & $\begin{array}{l}0.816^{* *} \\
(0.342)\end{array}$ & $\begin{array}{l}-0.429 * \\
(0.234)\end{array}$ & $\begin{array}{l}-1.074 * * * \\
(0.241)\end{array}$ \\
\hline Hours After School Writing Homework Mother Reported & $\begin{array}{l}-0.347 \\
(0.540)\end{array}$ & $\begin{array}{l}0.351 \\
(0.420)\end{array}$ & $\begin{array}{l}-0.595 * * \\
(0.248)\end{array}$ & $\begin{array}{l}-0.885^{* *} \\
(0.392)\end{array}$ \\
\hline Hours After School Homework Child Reported & $\begin{array}{l}-0.151 \\
(0.496)\end{array}$ & $\begin{array}{l}-0.541 \\
(0.399)\end{array}$ & $\begin{array}{l}-0.271 \\
(0.243)\end{array}$ & $\begin{array}{l}-0.792 \\
(0.483)\end{array}$ \\
\hline $\begin{array}{l}\text { Hours In School Homework } \\
\text { Child Reported }\end{array}$ & $\begin{array}{l}1.464^{*} \\
(0.767)\end{array}$ & $\begin{array}{l}1.458 * * \\
(0.681)\end{array}$ & $\begin{array}{l}-0.867 \\
(0.590)\end{array}$ & $\begin{array}{l}0.197 \\
(0.391)\end{array}$ \\
\hline
\end{tabular}

Robust Standard errors in parentheses.

* significant at $10 \%$; ** significant at $5 \%$; *** significant at $1 \%$.

Regression covariates also included mother's high grade, gender, birth order, marital status of mother, urban, grade, age, and year. 
Table 6: PIAT Math Raw Score - Difference-in-Difference-in-Differences Estimation U.S. Model - By Age Group

\begin{tabular}{|c|c|c|c|c|c|}
\hline & All & $7 \& 8$ & $9 \& 10$ & $11 \& 12$ & $13 \& 14$ \\
\hline \multirow[t]{2}{*}{ Policy*CT*Black } & $-2.327 * * *$ & $-3.463 * * *$ & 0.487 & -0.734 & $-6.379 * * *$ \\
\hline & $(0.543)$ & (1.017) & $(0.658)$ & $(0.891)$ & $(0.897)$ \\
\hline \multirow{2}{*}{ Policy*CT*Hisp. } & -0.678 & 1.083 & -1.015 & 0.698 & -2.013 \\
\hline & $(0.918)$ & (1.298) & (1.387) & (1.349) & (1.823) \\
\hline \multirow[t]{2}{*}{ Black } & $-5.573 * * *$ & $-5.704 * * *$ & $-5.093 * * *$ & $-5.270 * * *$ & $-6.270 * * *$ \\
\hline & $(0.396)$ & $(0.388)$ & $(0.462)$ & $(0.568)$ & $(0.657)$ \\
\hline \multirow[t]{2}{*}{ Hispanic } & $-3.360 * * *$ & $-3.835 * * *$ & $-3.700 * * *$ & $-2.967 * * *$ & -1.920 \\
\hline & $(0.474)$ & $(0.529)$ & $(0.520)$ & $(0.825)$ & (1.223) \\
\hline \multirow[t]{2}{*}{ CalTex (CT) } & -0.123 & 0.231 & 0.117 & 0.259 & -1.156 \\
\hline & $(0.552)$ & $(0.271)$ & $(0.662)$ & $(0.765)$ & $(1.060)$ \\
\hline \multirow[t]{2}{*}{ Policy*Black } & -0.426 & 0.747 & -0.818 & -1.437 & 0.483 \\
\hline & $(0.378)$ & $(0.560)$ & $(0.557)$ & $(0.918)$ & $(0.719)$ \\
\hline \multirow[t]{2}{*}{ Policy*Hispanic } & -0.951 & -0.905 & -0.999 & -2.179 & -0.486 \\
\hline & $(0.915)$ & $(0.906)$ & (1.144) & (1.369) & $(1.690)$ \\
\hline \multirow[t]{2}{*}{ CalTex*Black } & 0.499 & -0.095 & 0.272 & 0.270 & 1.212 \\
\hline & $(0.458)$ & $(0.535)$ & $(0.463)$ & $(0.552)$ & $(1.127)$ \\
\hline \multirow[t]{2}{*}{ CalTex*Hispanic } & -0.691 & -0.541 & 0.476 & $-1.908 * *$ & -2.042 \\
\hline & $(0.540)$ & $(0.488)$ & $(0.519)$ & $(0.868)$ & $(1.394)$ \\
\hline \multirow[t]{2}{*}{ Policy*CalTex } & $1.040 * *$ & 0.821 & 0.034 & 0.456 & $3.276^{* * * *}$ \\
\hline & $(0.442)$ & $(0.664)$ & $(0.520)$ & $(0.945)$ & $(0.689)$ \\
\hline \multirow[t]{2}{*}{ Times Taken } & $0.364 * *$ & $0.823 *$ & $0.979 * * *$ & 0.267 & $0.695 * * *$ \\
\hline & $(0.143)$ & $(0.413)$ & $(0.248)$ & $(0.257)$ & $(0.245)$ \\
\hline \multirow[t]{2}{*}{ Female } & $-1.202 * * *$ & -0.391 & $-1.479 * * *$ & $-1.651^{* * *}$ & $-1.491^{* * *}$ \\
\hline & $(0.302)$ & $(0.345)$ & $(0.374)$ & $(0.371)$ & $(0.478)$ \\
\hline \multirow[t]{2}{*}{ Grade } & $4.026 * * *$ & $4.662 * * *$ & $13.629 * * *$ & $8.790 * * *$ & $11.475^{* * *}$ \\
\hline & $(0.331)$ & $(1.030)$ & $(1.344)$ & $(2.369)$ & $(2.598)$ \\
\hline \multirow[t]{2}{*}{ Grade $^{2}$} & -0.036 & -0.407 & $-1.214^{* * *}$ & $-0.441 * *$ & $-0.531^{* * *}$ \\
\hline & $(0.034)$ & $(0.251)$ & $(0.163)$ & $(0.195)$ & $(0.177)$ \\
\hline \multirow[t]{2}{*}{ Child's Age (Months) } & $1.012 * * *$ & 0.443 & 0.032 & -0.598 & $-4.545^{* * *}$ \\
\hline & $(0.059)$ & $(0.564)$ & $(0.593)$ & (1.069) & (1.678) \\
\hline \multirow[t]{2}{*}{ Child's Age ${ }^{2}$} & $-0.004 * * *$ & -0.000 & -0.000 & 0.002 & $0.013^{* *}$ \\
\hline & $(0.000)$ & $(0.003)$ & $(0.002)$ & $(0.004)$ & $(0.005)$ \\
\hline \multirow[t]{2}{*}{ Mother's High Grade } & $0.995 * * *$ & $0.997 * * *$ & $0.942 * * *$ & $0.955 * * *$ & $1.079 * * *$ \\
\hline & $(0.079)$ & $(0.086)$ & $(0.087)$ & $(0.111)$ & $(0.101)$ \\
\hline \multirow[t]{2}{*}{ Urban } & 0.378 & $0.625^{*}$ & 0.470 & 0.505 & -0.442 \\
\hline & $(0.276)$ & $(0.329)$ & $(0.321)$ & $(0.394)$ & $(0.626)$ \\
\hline \multirow[t]{2}{*}{ Birth Order } & $-0.599 * * *$ & $-0.429 * *$ & $-0.475^{*}$ & $-0.670 * * *$ & $-0.879 * * *$ \\
\hline & $(0.173)$ & $(0.196)$ & $(0.236)$ & $(0.204)$ & $(0.197)$ \\
\hline \multirow[t]{2}{*}{ Constant } & $-48.264 * * *$ & -28.003 & -3.100 & 54.727 & $378.233^{* * *}$ \\
\hline & $(3.411)$ & $(26.706)$ & $(34.011)$ & $(72.761)$ & $(135.741)$ \\
\hline Observations & 17417 & 5036 & 4950 & 4443 & 2988 \\
\hline R-squared & 0.59 & 0.35 & 0.30 & 0.25 & 0.23 \\
\hline
\end{tabular}

Robust standard errors in parentheses.Year dummy variables suppressed.

* significant at $10 \%$; ** significant at $5 \%$; *** significant at $1 \%$ 
Table 7: PIAT Math - Policy Impact on Blacks by Model Specification and Age Group

\begin{tabular}{|c|c|c|c|c|c|}
\hline Model & All & $7 \& 8$ & $9 \& 10$ & $11 \& 12$ & $13 \& 14$ \\
\hline Primary & $\begin{array}{l}-2.327 * * * \\
(0.543)\end{array}$ & $\begin{array}{l}-3.463^{* * *} \\
(1.017)\end{array}$ & $\begin{array}{l}0.487 \\
(0.658)\end{array}$ & $\begin{array}{l}-0.734 \\
(0.891)\end{array}$ & $\begin{array}{l}-6.378^{* * *} \\
(0.897)\end{array}$ \\
\hline $\begin{array}{l}\text { CA \& TX } \\
\text { Only }\end{array}$ & $\begin{array}{l}-2.545^{*} \\
(0.309)\end{array}$ & $\begin{array}{l}-2.942 \\
(0.558)\end{array}$ & $\begin{array}{l}-0.748 \\
(0.316)\end{array}$ & $\begin{array}{l}-1.967^{*} \\
(0.223)\end{array}$ & $\begin{array}{l}-5.320 * * * \\
(0.014)\end{array}$ \\
\hline CA vs. U.S. & $\begin{array}{l}-3.062 * * * \\
(0.365)\end{array}$ & $\begin{array}{l}-4.687 * * * \\
(0.574)\end{array}$ & $\begin{array}{l}0.347 \\
(0.597)\end{array}$ & $\begin{array}{l}-1.682^{*} \\
(0.852)\end{array}$ & $\begin{array}{l}-7.656 * * * \\
(0.879)\end{array}$ \\
\hline TX vs. U.S. & $\begin{array}{l}-1.823 * * * \\
(0.382)\end{array}$ & $\begin{array}{l}-2.163 * * * \\
(0.558)\end{array}$ & $\begin{array}{l}1.336 * * \\
(0.599)\end{array}$ & $\begin{array}{l}-0.893 \\
(0.908)\end{array}$ & $\begin{array}{l}-6.169 * * * \\
(0.802)\end{array}$ \\
\hline $\begin{array}{l}\text { Blacks } \\
\text { Only }\end{array}$ & $\begin{array}{l}-1.274^{*} \\
(0.745)\end{array}$ & $\begin{array}{l}-2.607 * * \\
(1.117)\end{array}$ & $\begin{array}{l}0.237 \\
(0.641)\end{array}$ & $\begin{array}{l}-0.182 \\
(1.114)\end{array}$ & $\begin{array}{l}-3.218 * * * \\
(1.099)\end{array}$ \\
\hline $\begin{array}{l}\text { Year } 1996 \\
\text { Omitted }\end{array}$ & $\begin{array}{l}-2.110^{* * *} \\
(0.503)\end{array}$ & $\begin{array}{l}-3.225 * * * \\
(0.844)\end{array}$ & $\begin{array}{l}1.011 \\
(0.851)\end{array}$ & $\begin{array}{l}-1.279 \\
(0.945)\end{array}$ & $\begin{array}{l}-6.000 * * * \\
(0.841)\end{array}$ \\
\hline $\begin{array}{l}\text { Washington } \\
\text { Included }\end{array}$ & $\begin{array}{l}-2.098^{* * *} \\
(0.610)\end{array}$ & $\begin{array}{l}-3.380 * * * \\
(0.994)\end{array}$ & $\begin{array}{l}-0.123 \\
(0.855)\end{array}$ & $\begin{array}{l}-0.177 \\
(1.135)\end{array}$ & $\begin{array}{l}-5.195 * * * \\
(1.510)\end{array}$ \\
\hline $\begin{array}{l}\text { Florida } \\
\text { Included }\end{array}$ & $\begin{array}{l}-1.341^{*} \\
(0.797)\end{array}$ & $\begin{array}{l}-2.802 * * * \\
(0.937)\end{array}$ & $\begin{array}{l}1.311^{*} \\
(0.653)\end{array}$ & $\begin{array}{l}-0.292 \\
(0.718)\end{array}$ & $\begin{array}{l}-4.372^{* *} \\
(1.720)\end{array}$ \\
\hline $\begin{array}{l}\text { Mississippi } \\
\text { Included }\end{array}$ & $\begin{array}{l}-2.537 * * * \\
(0.512)\end{array}$ & $\begin{array}{l}-3.521 * * * \\
(0.846)\end{array}$ & $\begin{array}{l}-0.234 \\
(1.005)\end{array}$ & $\begin{array}{l}-1.162 \\
(0.917)\end{array}$ & $\begin{array}{l}-5.459 * * * \\
(1.365)\end{array}$ \\
\hline $\begin{array}{l}\text { Louisiana } \\
\text { Included }\end{array}$ & $\begin{array}{l}-2.167 * * * \\
(0.411)\end{array}$ & $\begin{array}{l}-3.614 * * * \\
(0.810)\end{array}$ & $\begin{array}{l}0.591 \\
(0.637)\end{array}$ & $\begin{array}{l}-0.705 \\
(0.882)\end{array}$ & $\begin{array}{l}-5.016 * * * \\
(1.387)\end{array}$ \\
\hline $\begin{array}{l}\text { Mother's } \\
\text { AFQT }\end{array}$ & $\begin{array}{l}-2.000 * * * \\
(0.466)\end{array}$ & $\begin{array}{l}-2.790 * * * \\
(0.829)\end{array}$ & $\begin{array}{l}0.901 \\
(0.713)\end{array}$ & $\begin{array}{l}-0.876 \\
(0.943)\end{array}$ & $\begin{array}{l}-5.938 * * * \\
(0.912)\end{array}$ \\
\hline $\begin{array}{l}\text { Net Family } \\
\text { Income }\end{array}$ & $\begin{array}{l}-2.314^{* * *} \\
(0.475)\end{array}$ & $\begin{array}{l}-3.902 * * * \\
(0.900)\end{array}$ & $\begin{array}{l}1.518 * * \\
(0.653)\end{array}$ & $\begin{array}{l}-0.465 \\
(0.949)\end{array}$ & $\begin{array}{l}-6.994 * * * \\
(1.177)\end{array}$ \\
\hline $\begin{array}{l}\text { Marital } \\
\text { Status }\end{array}$ & $\begin{array}{l}-1.977 * * * \\
(0.562)\end{array}$ & $\begin{array}{l}-3.285 * * * \\
(1.098)\end{array}$ & $\begin{array}{l}0.796 \\
(0.648)\end{array}$ & $\begin{array}{l}-0.077 \\
(0.882)\end{array}$ & $\begin{array}{l}-6.069 * * * \\
(0.966)\end{array}$ \\
\hline Family Size & $\begin{array}{l}-2.335^{* * *} \\
(0.535)\end{array}$ & $\begin{array}{l}-3.459 * * * \\
(1.025)\end{array}$ & $\begin{array}{l}0.469 \\
(0.640)\end{array}$ & $\begin{array}{l}-0.683 \\
(0.888)\end{array}$ & $\begin{array}{l}-6.366 * * * \\
(0.891)\end{array}$ \\
\hline $\begin{array}{l}\text { Net Income } \\
\text { \& Marital }\end{array}$ & $\begin{array}{l}-2.043 * * * \\
(0.578)\end{array}$ & $\begin{array}{l}-3.771 * * * \\
(0.919)\end{array}$ & $\begin{array}{l}1.705^{* *} \\
(0.678)\end{array}$ & $\begin{array}{l}0.086 \\
(0.923)\end{array}$ & $\begin{array}{l}-6.802 * * * \\
(1.228)\end{array}$ \\
\hline $\begin{array}{l}\text { Net Income \& } \\
\text { Family Size }\end{array}$ & $\begin{array}{l}-2.313^{* * *} \\
(0.476)\end{array}$ & $\begin{array}{l}-3.913 * * * \\
(0.902)\end{array}$ & $\begin{array}{l}1.479 * * \\
(0.652)\end{array}$ & $\begin{array}{l}-0.350 \\
(0.963)\end{array}$ & $\begin{array}{l}-6.989 * * * \\
(1.182)\end{array}$ \\
\hline $\begin{array}{l}\text { Marital \& } \\
\text { Family Size }\end{array}$ & $\begin{array}{l}-1.963 * * * \\
(0.564)\end{array}$ & $\begin{array}{l}-3.193 * * * \\
(1.131)\end{array}$ & $\begin{array}{l}0.869 \\
(0.649)\end{array}$ & $\begin{array}{l}-0.108 \\
(0.876)\end{array}$ & $\begin{array}{l}-6.087 * * * \\
(0.959)\end{array}$ \\
\hline All & $\begin{array}{l}-2.024^{* * *} \\
(0.507) \\
\end{array}$ & $\begin{array}{l}-3.676 * * * \\
(0.953) \\
\end{array}$ & $\begin{array}{l}1.731^{* *} \\
(0.687)\end{array}$ & $\begin{array}{l}0.087 \\
(0.926)\end{array}$ & $\begin{array}{l}-6.792 * * * \\
(1.228)\end{array}$ \\
\hline
\end{tabular}

Robust standard errors in parentheses

* significant at $10 \%$; ** significant at $5 \%$; *** significant at $1 \%$

Regression covariates also included mother's high grade, gender, birth order, urban, grade, age, number of times child has taken the test, and year. 
Table 8: PIAT Math - Policy Impact by Race/Ethnicity, Age, and Mother's Education

\begin{tabular}{|c|c|c|c|c|c|}
\hline & All & $7 \& 8$ & $9 \& 10$ & $11 \& 12$ & $13 \& 14$ \\
\hline \multicolumn{6}{|c|}{ Policy*CalTex* Black } \\
\hline Mother's & -1.210 & -2.355 & 0.379 & 0.069 & $-3.391 * *$ \\
\hline Education $<13$ & $(0.785)$ & $(2.727)$ & $(0.994)$ & $(1.234)$ & $(1.287)$ \\
\hline Mother's & $-4.043 * * *$ & $-4.485 * * *$ & -1.277 & -1.506 & $-7.821 * * *$ \\
\hline Education $13+$ & $(1.036)$ & $(1.243)$ & $(1.350)$ & $(1.997)$ & $(1.882)$ \\
\hline \multicolumn{6}{|c|}{ Policy*CalTex* Hispanic } \\
\hline Mother's & -0.639 & 0.267 & -0.383 & 1.384 & -2.736 \\
\hline Education $<13$ & $(1.231)$ & (1.861) & (1.189) & $(1.740)$ & $(2.257)$ \\
\hline Mother's & -0.727 & 1.978 & -3.989 & 0.498 & $4.259 *$ \\
\hline Education 13+ & $(1.035)$ & (1.917) & (2.579) & (1.857) & $(2.265)$ \\
\hline
\end{tabular}

Robust standard errors in parentheses.

* significant at $10 \%$; ** significant at $5 \%$; *** significant at $1 \%$

Regression covariates also included mother's high grade, gender, birth order, urban, grade, age, number of times child has taken the test, and year. 
Table 9: PIAT Math - Rate of Growth in Test Scores - Individual Fixed Effects Model

\begin{tabular}{|c|c|c|c|c|}
\hline & $\begin{array}{c}\text { U.S. } \\
(1990-1994) \\
\end{array}$ & $\begin{array}{c}\text { U.S. } \\
(1996-2000)\end{array}$ & $\begin{array}{c}\text { CalTex Only } \\
(1996-2000)\end{array}$ & $\begin{array}{c}\text { Blacks Only } \\
(1996-2000)\end{array}$ \\
\hline Policy*Black & $\begin{array}{l}-1.607 \\
(0.979)\end{array}$ & $\begin{array}{l}-0.426 \\
(1.129)\end{array}$ & $\begin{array}{l}-7.190 * * * \\
(2.409)\end{array}$ & \\
\hline Policy*Hispanic & $\begin{array}{l}-0.924 \\
(1.907)\end{array}$ & $\begin{array}{l}2.736 * \\
(1.431)\end{array}$ & $\begin{array}{l}-3.386 \\
(2.211)\end{array}$ & \\
\hline Policy*CalTex & $\begin{array}{l}0.875 \\
(2.301)\end{array}$ & $\begin{array}{l}1.530 \\
(1.382)\end{array}$ & & $\begin{array}{l}-5.606 * * * \\
(1.812)\end{array}$ \\
\hline Policy*CalTex*Black & $\begin{array}{l}-0.808 \\
(2.758)\end{array}$ & $\begin{array}{l}-7.092^{* * *} \\
(2.618)\end{array}$ & & \\
\hline Policy*CalTex*Hispanic & $\begin{array}{l}-3.183 \\
(3.112)\end{array}$ & $\begin{array}{l}-5.936 * * * \\
(2.174)\end{array}$ & & \\
\hline Times Taken & $\begin{array}{l}0.566 \\
(2.018)\end{array}$ & $\begin{array}{l}0.475 \\
(1.914)\end{array}$ & $\begin{array}{l}-3.079 \\
(3.058)\end{array}$ & $\begin{array}{l}2.098 \\
(3.335)\end{array}$ \\
\hline Mother's High Grade & $\begin{array}{l}0.272 \\
(0.334)\end{array}$ & $\begin{array}{l}0.456 \\
(0.679)\end{array}$ & $\begin{array}{l}0.283 \\
(0.539)\end{array}$ & $\begin{array}{l}0.804 \\
(2.084)\end{array}$ \\
\hline Year2000 & $\begin{array}{l}12.412^{* * * *} \\
(4.237)\end{array}$ & $\begin{array}{l}13.200 * * \\
(4.934)\end{array}$ & $\begin{array}{l}18.829 * * \\
(8.298)\end{array}$ & $\begin{array}{l}6.351 \\
(8.299)\end{array}$ \\
\hline Grade & $\begin{array}{l}5.267 * * * \\
(0.921)\end{array}$ & $\begin{array}{l}4.507 * * * \\
(0.793)\end{array}$ & $\begin{array}{l}4.522^{* * *} \\
(1.235)\end{array}$ & $\begin{array}{l}6.306^{* * *} \\
(1.521)\end{array}$ \\
\hline Grade $^{2}$ & $\begin{array}{l}-0.467 * * * \\
(0.070)\end{array}$ & $\begin{array}{l}-0.404^{* * *} \\
(0.050)\end{array}$ & $\begin{array}{l}-0.347^{* * *} \\
(0.070)\end{array}$ & $\begin{array}{l}-0.513^{* * *} \\
(0.089)\end{array}$ \\
\hline Constant & $\begin{array}{l}19.914 * * * \\
(6.361)\end{array}$ & $\begin{array}{l}22.855^{*} \\
(11.701)\end{array}$ & $\begin{array}{l}34.270 * * * \\
(11.485)\end{array}$ & $\begin{array}{l}6.607 \\
(31.962)\end{array}$ \\
\hline Observations & 1770 & 1304 & 290 & 360 \\
\hline Number of Children & 885 & 652 & 145 & 180 \\
\hline R-squared & 0.79 & 0.79 & 0.79 & 0.78 \\
\hline
\end{tabular}

Robust standard errors in parentheses

* significant at $10 \%$; ** significant at $5 \%$; *** significant at $1 \%$ 
Figure 1: Admit Rates California First Time Freshman Applicants - University of California System

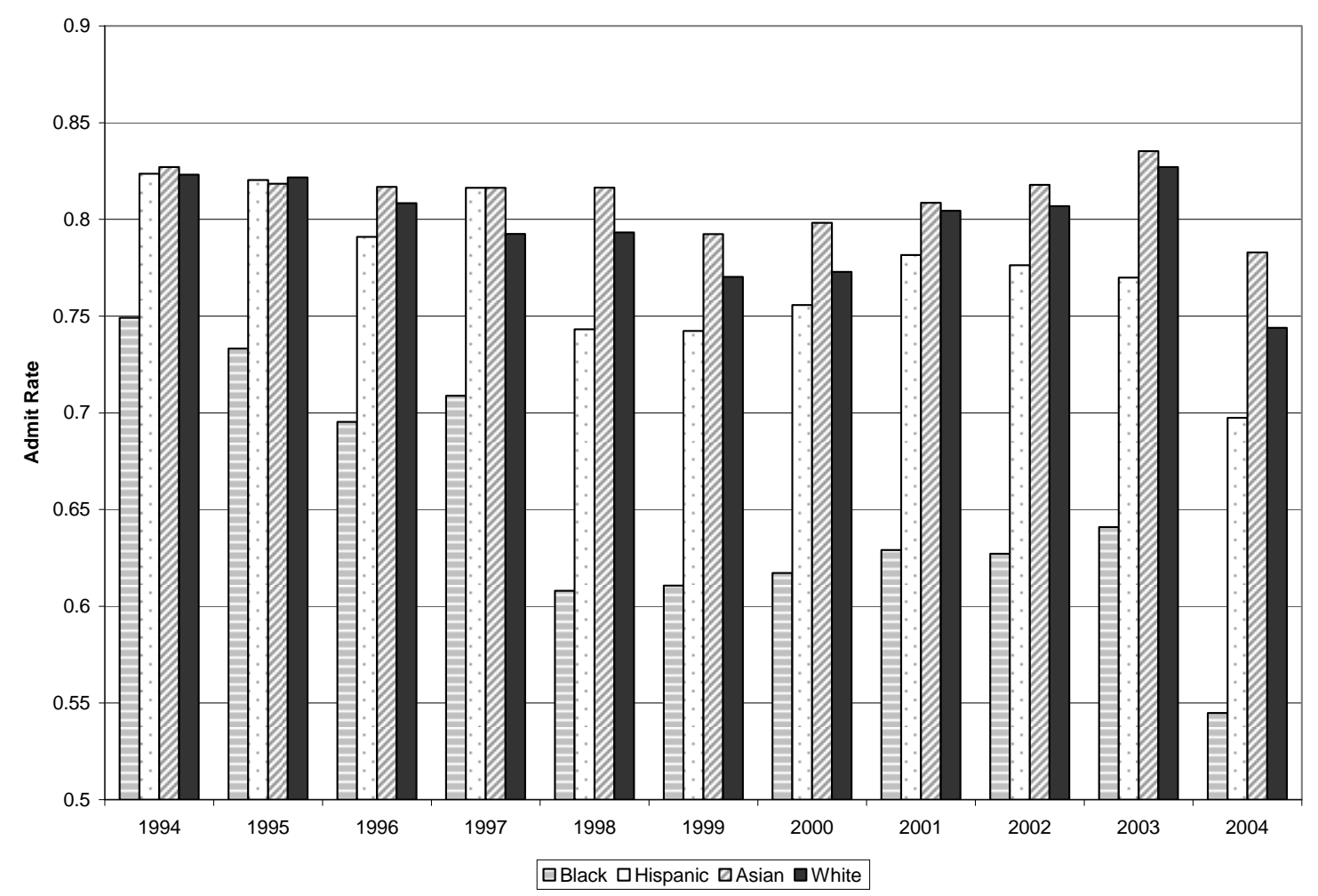

Source: University of California StatFinder 
Figure 2: UC System Black Application and Admit Rates as a Percent of Total 18 Year Old Black Population in California

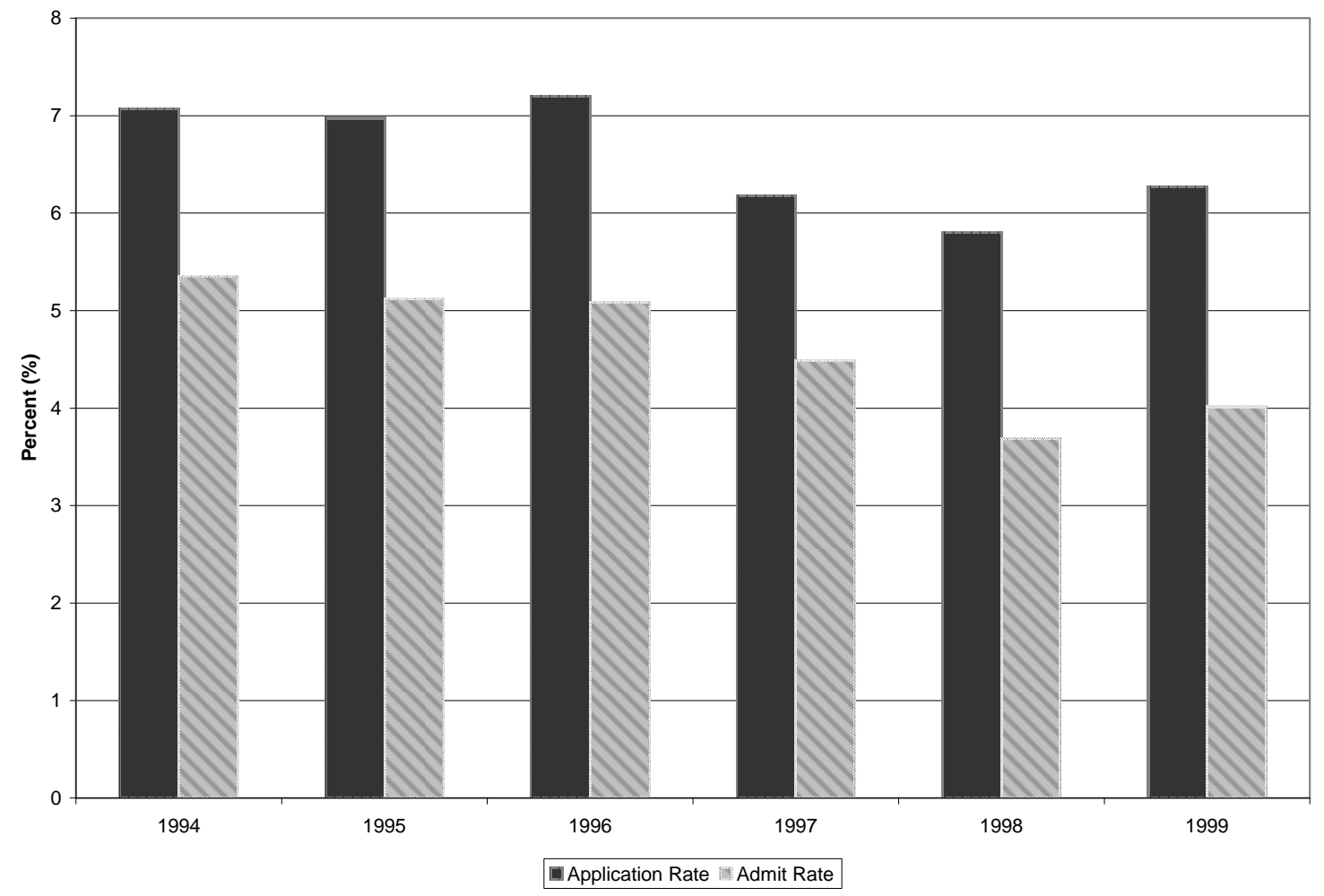

Sources: University of California StatFinder and U.S. Census population data. 
Figure 3: Admit Rates California First Time Freshman Black Applicants

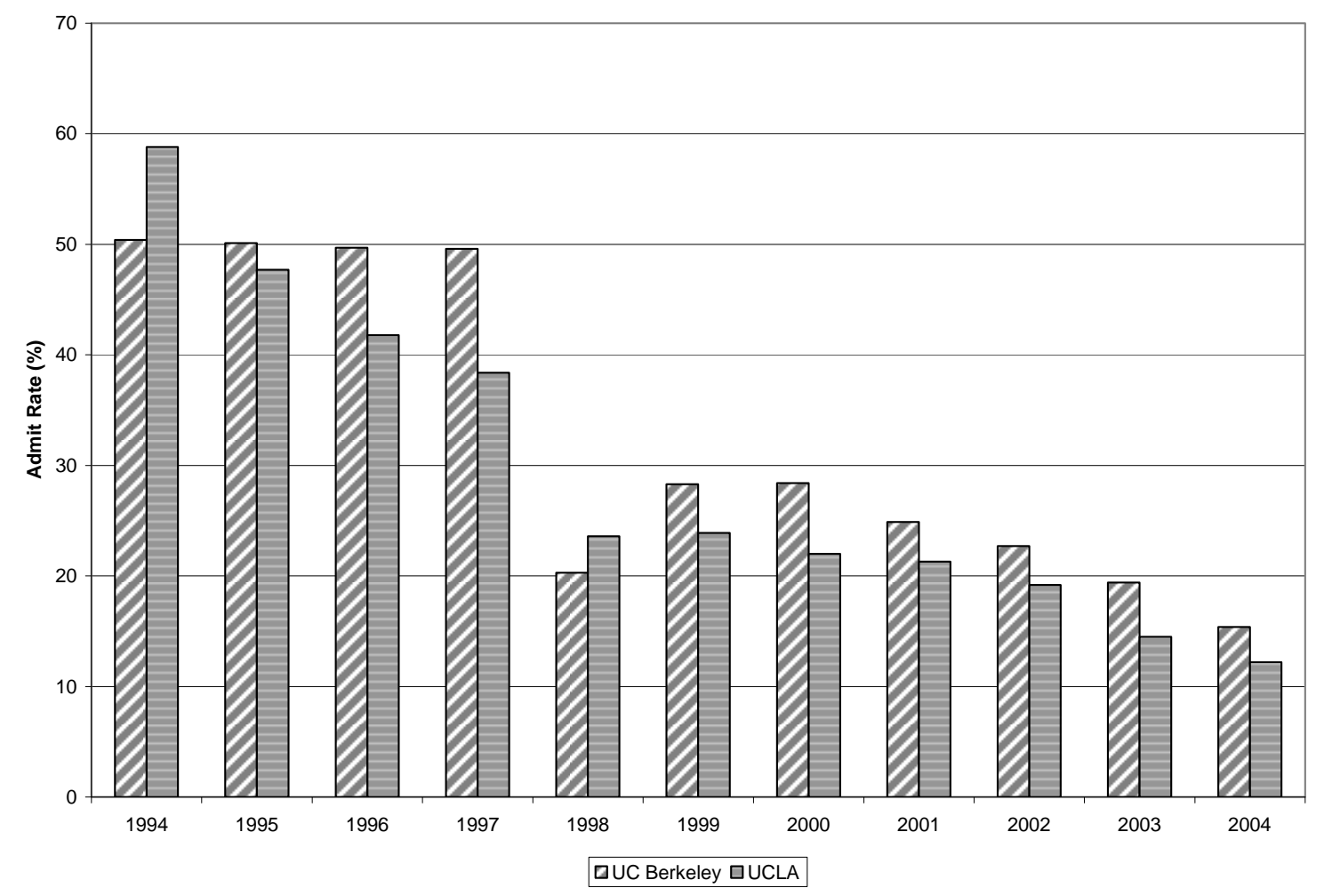

Source: University of California StatFinder 
Figure 4: Kernel Density Distribution: PIAT Math Scores 13 \& 14 Year Olds

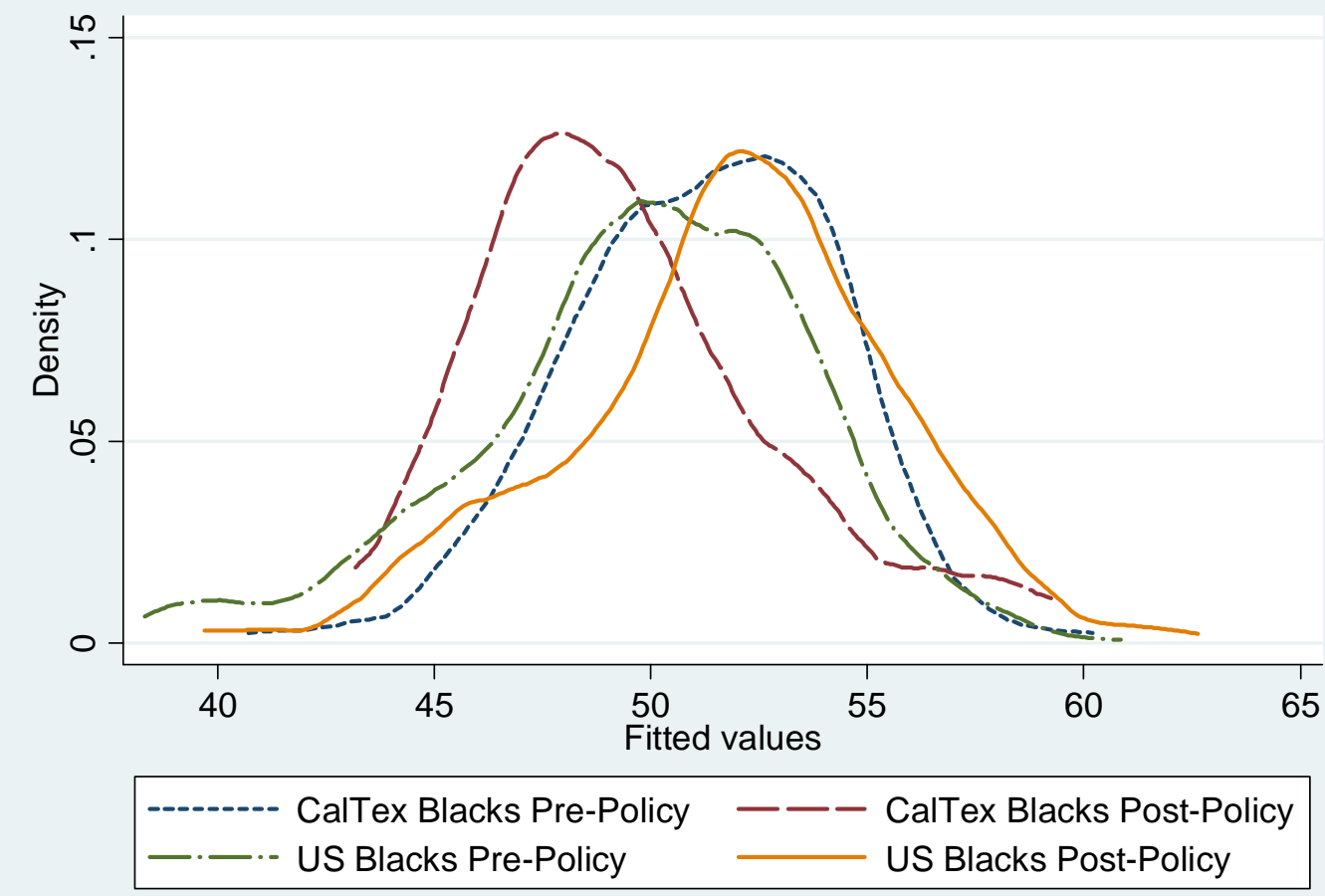

kernel $=$ epanechnikov, bandwidth $=1.0499$ 
Figure 5: Kernel Density Distribution: PIAT Math Scores 13 \& 14 Year Olds

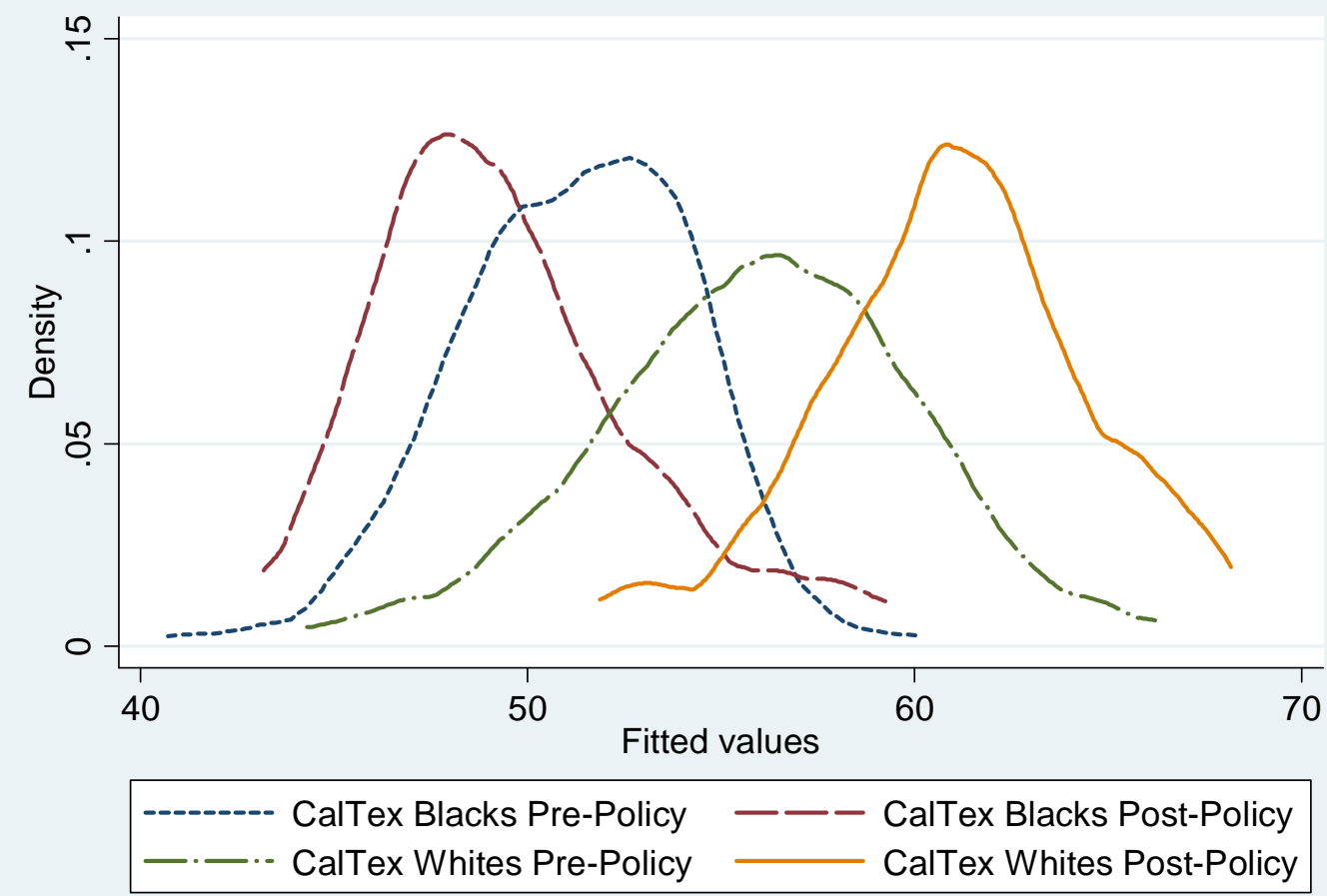

kernel $=$ epanechnikov, bandwidth $=1.0499$ 
Figure 6: Growth in PIAT Math Scores 1996 to 2000

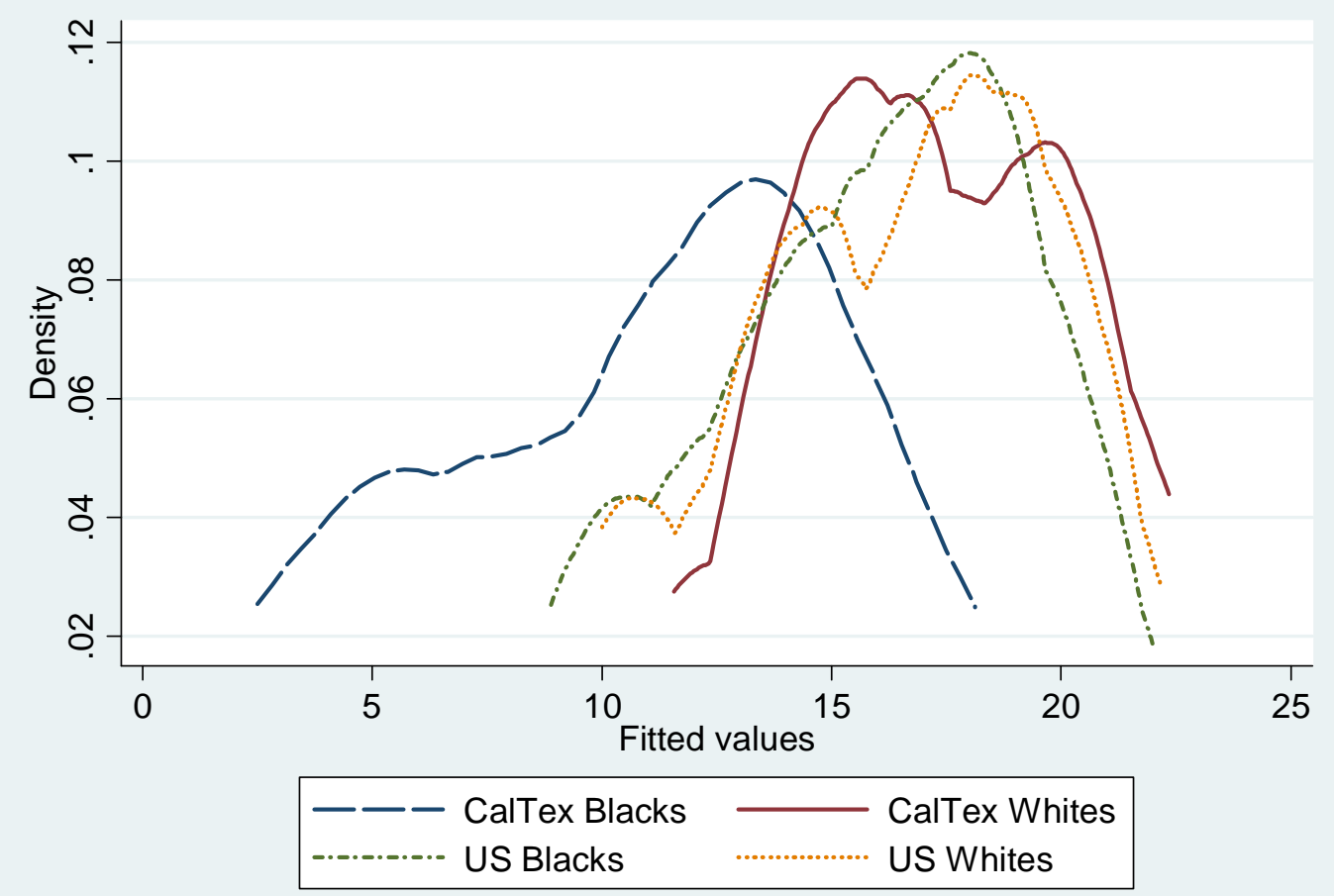

kernel $=$ epanechnikov, bandwidth $=1.9937$ 